\title{
Analytical programme and applied methods
}

\author{
F. G. Christiansen, J. Boserup, B. Buchardt, C. Guvad, K. Hansen, C. J. W. Koch, \\ J. Jensenius, G.S. Nielsen, H. Nøhr-Hansen, S. Stouge, E. Thomsen and P. Østfeldt
}

The laboratory phase of the 'Nordolie' project included geochemical, microscopical and petrophysical methods (fig. 9). These methods vary considerably in approach and degree of sophistication. Laboratory work has been carried out in Copenhagen at the laboratories of the Geological Survey of Greenland (GGU), the Geological Survey of Denmark (DGU), and the Geological Institute, University of Copenhagen.

\section{Sampling}

Considerable time was devoted to stratigraphic, sedimentological and structural studies of potential reservoir and source rock sequences with the highest priority during field work given to sampling of fine-grained units for analytical work. During the summers of 1984 and 1985 two teams carried out field work and sampling from 33 camp sites in central and western North Green-

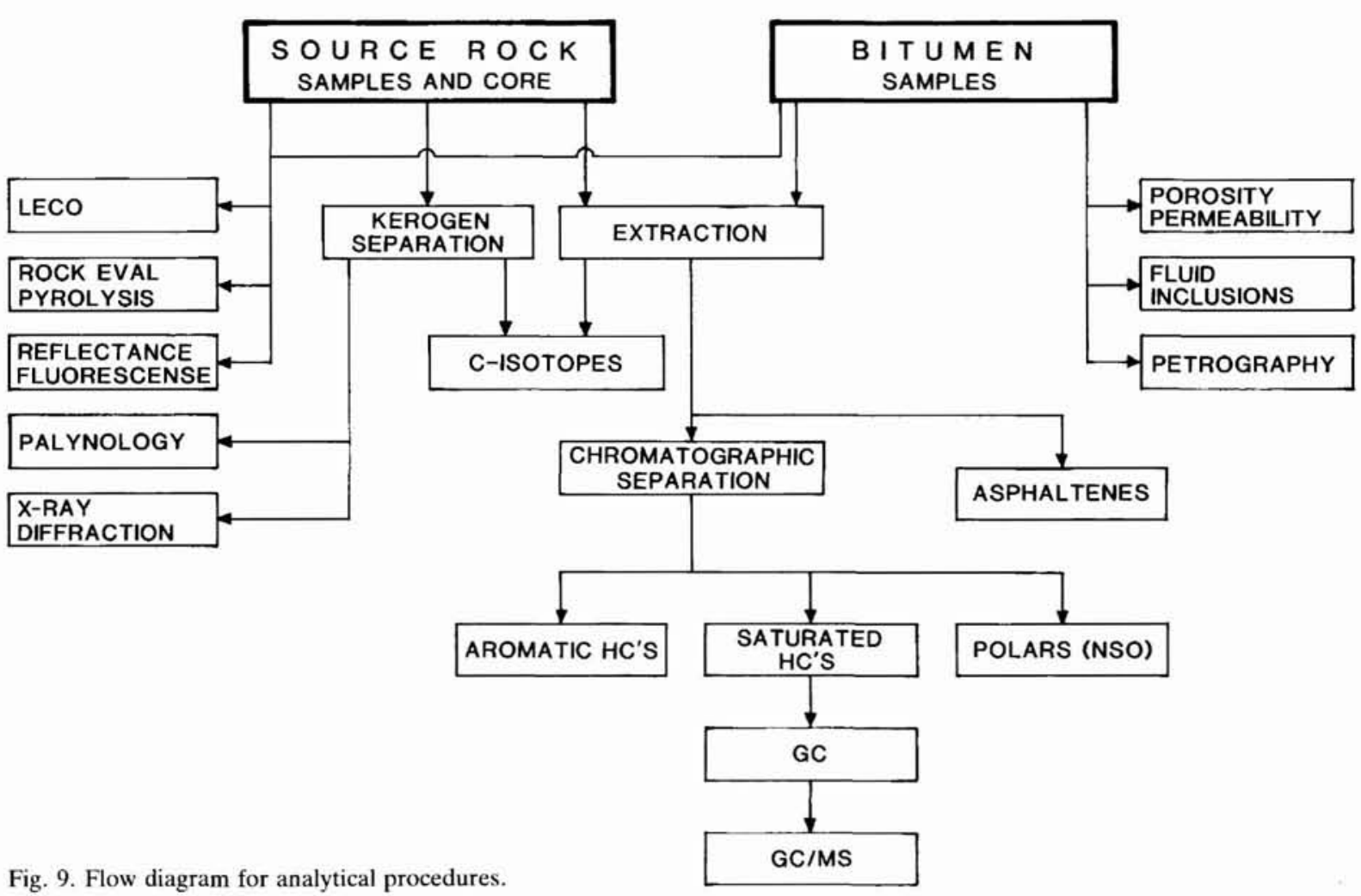

Fig. 9. Flow diagram for analytical procedures. 
land (Christiansen \& Rolle, 1985; Christiansen et al., 1986); approximately 70 localities were visited by helicopter. In addition to the 989 samples collected by geologists directly involved in the source rock study, a limited number of samples (approximately 75) collected by other geologists were also studied. The study of the Peary Land region, which is only briefly treated in the present work, is mainly based on 275 samples collected by Flemming Rolle in 1980 (Rolle, 1981) plus approximately 50 samples collected by a number of other geologists in 1978 to 1980.

The samples collected were selected to be representative of the studied interval. Whenever possible, samples were collected from unweathered intervals below the surface, as weathering is known to influence the organic geochemistry of surface samples (Leythaeuser, 1973; Clayton \& Swetland, 1978; Forsberg \& Bjorøy, 1983). All samples were wrapped in aluminium foil to avoid contamination during transport and storage. So far no contaminants have been detected in any of the analysed surface samples.

\section{Drilling programme}

A drilling programme was carried out in order to obtain unweathered and statistically representative samples of the most interesting source rock units (see Christiansen et al., 1986 for details). The drilling unit, which was constructed and later modified a number of times by J. Boserup and A. Clausen at GGU, has been successfully employed in Jameson Land, East Greenland (Surlyk, 1983; Surlyk et al., 1984), in North Greenland (Christiansen et al., 1986), and on Traill $\emptyset$, East Greenland (Marcussen et al., 1987).

Thirteen holes were drilled to a maximum depth of 40 $\mathrm{m}$. Approximately 345 cumulative metres were drilled and except for the uppermost metres at each site the recovery was close to $100 \%$. All cores were described at the drill site using a scale of 1:50 or 1:100 and most holes were logged by gamma ray measurements (logs of the Silurian cores are shown by Christiansen \& Nøhr-Hansen, 1989).

After logging, the core pieces were wrapped in aluminium foil and packed in standard core boxes made of hard plastic. Unfortunately, the plastic seems to have caused minor contamination with $\mathrm{C}_{12}, \mathrm{C}_{14}, \mathrm{C}_{16}, \mathrm{C}_{18}, \mathrm{C}_{20}$ $n$-alkanes in some of the analysed core samples (see fig. 11).

\section{Handling and storage}

All samples and core boxes were transported to Copenhagen by air during or shortly after the two field seasons. The sampled material is stored at GGU, mostly in closed standard sample cases. During preparation (e.g. cutting, crushing) contact with equipment or containers made of organic compounds (e.g. rubber, plastic) was avoided.

\section{LECO and Rock Eval pyrolysis}

The LECO and Rock Eval analyses were carried out at the source rock laboratories at DGU and GGU. More than 600 samples were analysed, mainly during the months immediately following the two field seasons with later supplementary analyses of a smaller number of specific samples. Both types of analyses are based on crushed whole rock material using $200 \mathrm{mg}$ and $100 \mathrm{mg}$ of sample, respectively.

The total carbon content (TC), the total organic carbon content (TOC), and hence the total inorganic carbon content $(\mathrm{TIC}=\mathrm{TC}-\mathrm{TOC})$ were determined by combustion in a LECO IR 212 furnace before and after treatment with hot concentrated $\mathrm{HCl}$, respectively.

The Rock Eval pyrolysis method (Espitalié et al., 1977 ) is universally applied by oil and service companies in the characterization of source rock potential, types of organic matter, and thermal maturity (Horsfield $e t a l$., 1983; Horsfield, 1984; Tissot \& Welte, 1984). However, the method should be used with caution because of variation due to differences in material type and mineral matrix (Espitalié et al., 1980, 1984; Evans \& Felbeck, 1983; Katz, 1983) and presence of migrated bitumen (Clementz, 1979). In order to reduce errors and misinterpretations the material from North Greenland was analysed employing the same laboratory procedure and the same instrumentation throughout.

During the Rock Eval pyrolysis the powdered samples are heated at steadily increasing temperatures from $300^{\circ} \mathrm{C}$ to $550^{\circ} \mathrm{C}$. The release curve of the pyrolysate typically shows two peaks (fig. 10). The low temperature peak, $\mathrm{S} 1\left(\mathrm{mg} \mathrm{HC} / \mathrm{g}\right.$ rock) at $300^{\circ} \mathrm{C}$ is due to hydrocarbons already present in the sample. The second, $\mathrm{S} 2\left(\mathrm{mg} \mathrm{HC} / \mathrm{g}\right.$ rock) between $410^{\circ} \mathrm{C}$ and $520^{\circ} \mathrm{C}$, correlates with hydrocarbons generated by thermal alteration of the kerogen. The $\mathrm{CO}_{2}$ generated during pyrolysis in the temperature interval $300^{\circ} \mathrm{C}$ to $390^{\circ} \mathrm{C}$ is trapped and analysed by thermal conductivity detection as a third peak $\mathrm{S} 3$ ( $\mathrm{mg} \mathrm{CO} / \mathrm{g}$ rock). With increasing thermal maturity the area of the S2 peak decreases and the peak is displaced towards higher temperatures. The temperature of maximum generation $\left(T_{\max }\right)$ during pyrolysis is used as a maturity parameter (fig. 10). 


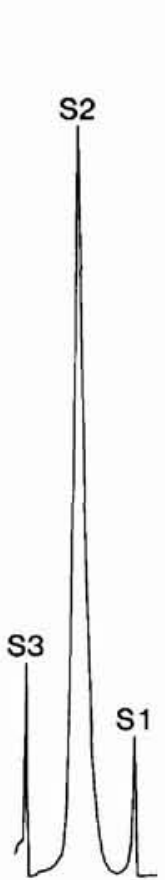

A

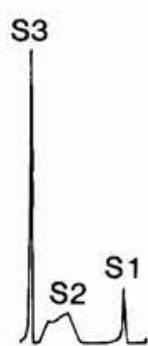

B s1

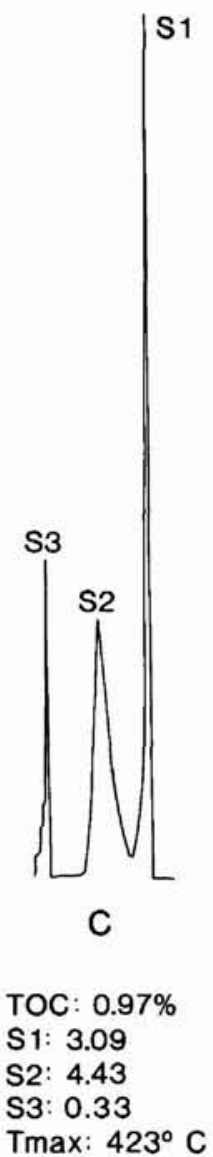

TOC : $2.82 \%$

S1: 0.64

S2: 14.20

S3: 0.62

Tmax: $432^{\circ} \mathrm{C}$

TOC: $2.26 \%$
S1: 0.16
S2: 0.81
S3: 0.30
Tmax: $465^{\circ} \mathrm{C}$

Fig. 10. Selected pyrogrammes showing typical relations of S1, $\mathrm{S} 2, \mathrm{~S} 3, T_{\max }$ and TOC for (A) immature to mature source rock (sample 316775, Lafayette Bugt Formation, Washington Land), (B) mature to postmature source rock (sample 324490. Thors Fjord Member, Warming Land), (C) bitumen-impregnated sandstone (sample 322205, Buen Formation, Wulff Land).

\section{Palynological studies}

Palynological preparation and studies were carried out at GGU. Kerogen from more than 455 samples was examined optically in order to obtain information on the Thermal Alteration Index (TAI), kerogen composition, relative kerogen content and content of palynomorphs.

The kerogen was separated from $20 \mathrm{~g}$ of each sample by standard palynological preparation, in which minerals are dissolved by $\mathrm{HCl}$ and $\mathrm{HF}$. The first slide was made after this acid treatment. The second slide was made of organic residue which had been sieved on a 10 micron nylon mesh. Occasionally a third slide was made after brief oxidation ( 3 to 5 minutes) with fuming $\mathrm{HNO}_{3}$ followed by washing with a weak $\mathrm{KOH}$ solution.

The organic residue was mounted in a permanent medium Eukitt ${ }^{\circledR}$ (produced by O. Kindler, West Germany). The first and second slides were used in the evaluation of maturity and kerogen content, the third for biostratigraphic purposes. The slides were studied with translucent microscopy applying an Olympus BH-2 microscope. The S.E.M. observations were carried out on Au-coated sieved and oxidized kerogen using a Cambridge or a Phillips Scanning Electron Microscope at the Geological Institute, University of Copenhagen.

\section{Gas chromatography and gas chromatography/mass spectrometry}

Gas chromatography (GC) and gas chromatography/ mass spectrometry (GC/MS) analyses were carried out at the source rock laboratories at DGU and GGU. Following preliminary interpretation based on screening methods (LECO/Rock Eval and palynological studies), 54 samples of source rocks and bitumen were selected for GC analysis. Sixteen of these samples were analysed using the GC/MS technique after evaluation of the gas chromatograms (checking for 'biomarkers' in the $\mathrm{C}_{27}$ to $\mathrm{C}_{32}$ range) (Østfeldt, 1987b). About 115 samples from Peary Land had been analysed prior to the initiation of the Nordolie project (Rolle \& Wrang, 1981). Many of these samples are, however, postmature and lean in organic material and provide only little information on the petroleum geology of the region.

Crushed samples (50-100 g except for the pure bitumens) were extracted with methylene chloride for $24 \mathrm{~h}$ in a Soxhlett extraction apparatus. The extract was filtered, the solvent removed by evaporation, and the amount of extract determined.

The extract $(50-100 \mathrm{mg}$ ) was separated on an open silica column by stepwise elution with $n$-hexane, methylene chloride and methanol, yielding saturated, aromatic and polar (= hetero compounds) fractions, respectively. Asphaltenes are retained on the column. After evaporation of the solvent, the weight of the individual fractions was determined, and the relative distribution of saturate (sa), aromatic (ar) and polar (po) compounds was calculated.

GC analyses of the total saturate fraction were carried out on a Hewlett Packard 5840 gas chromatograph, fitted with a $25 \mathrm{~m} \times 0.3 \mathrm{~mm}$ (int. diam.) fused silica capillary column coated with a cross-linked methyl silicone stationary phase. The column was operated from $80^{\circ}$ to $300^{\circ} \mathrm{C}$ at $6^{\circ} \mathrm{C} / \mathrm{min}$. and the effluent detected with a FID detector. From the gas chromatogram, the pristane 
to phytane $(\mathrm{Pr} / \mathrm{Ph})$ and pristane to $\mathrm{C}_{17} n$-alkane $(\mathrm{Pr} /$ $n \mathrm{C}_{17}$ ) ratios were calculated (see fig. 11).

GC/MS analyses were carried out using a Finngan $1020 \mathrm{GC} / \mathrm{MS}$ system connected with an on-column injector onto a $25 \mathrm{~m} \times 0.22 \mathrm{~mm}$ (int. diam.) fused silica capillary column coated with cross-linked methyl silicone phase. The column was operated from $70^{\circ}$ to $310^{\circ} \mathrm{C}$ at $5^{\circ} \mathrm{C} / \mathrm{min}$. The column led directly into the ion source of the mass spectrometer operating at an ionizing voltage of $70 \mathrm{eV}$.

The mass spectrometer was operated in the Multiple Ion Detection (MID) mode, scanning 10 ions (m/e 82, $123,177,183,191,205,217,218,231$, and 259) every second. From the integrated ion-chromatograms of $\mathrm{m} / \mathrm{e}$ 191 (triterpanes), 217 and 218 (steranes and diasteranes), several source, lithology and maturity-dependent parameters were calculated (see Østfeldt, 1987a,b for details). The other seven ion-chromatograms (not integrated) were used to support the tentative peak assignment.

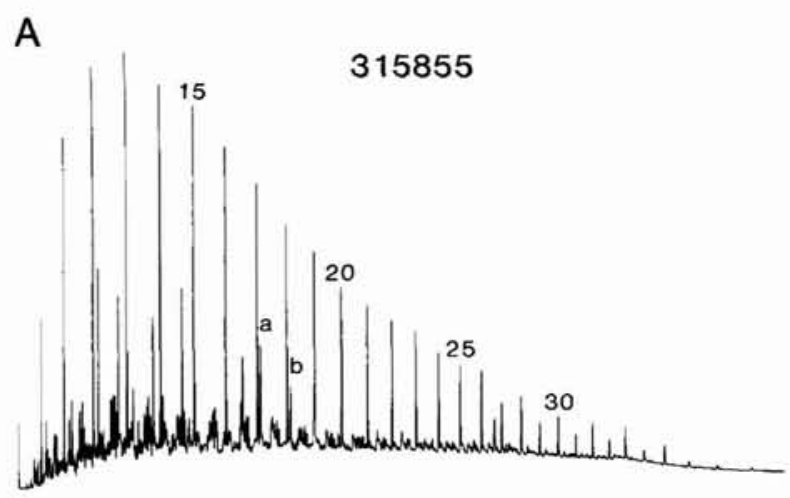

B

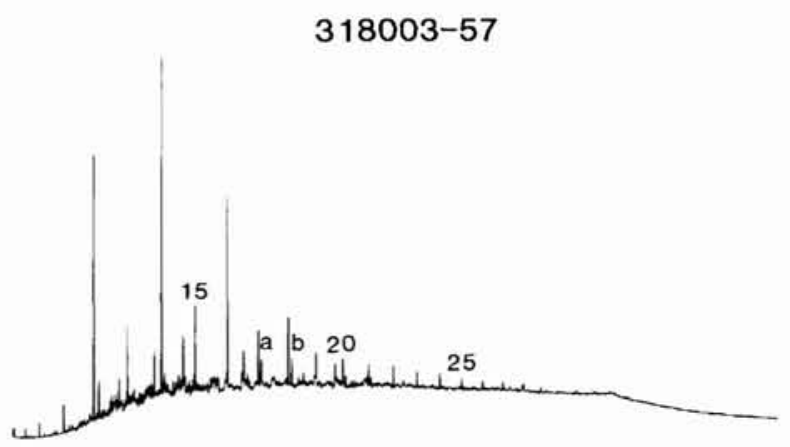

\section{Reflectance and fluorescence studies}

Reflectance and fluorescence measurements of graptolites, kerogen and bitumen were carried out at the source rock laboratories of DGU and GGU. The graptolite-rich samples were collected for initiation of a research programme on graptolite reflectance (Stouge $e t$ al., 1988) and about 45 samples were prepared shortly after the two field seasons. About 75 samples were selected for reflectance and fluorescence measurements of kerogen and bitumen after initial evaluation of screening data (Thomsen \& Guvad, 1987). Only samples with relatively high TOC values or visible fluorescence in the palynological slides were considered further.

The investigations were carried out on whole rock samples, either crushed to a grain size of 2 to $3 \mathrm{~mm}$ or prepared as rock fragments orientated perpendicular to the lamination. The samples were embedded in a cold setting epoxy resin and then ground and polished using

C

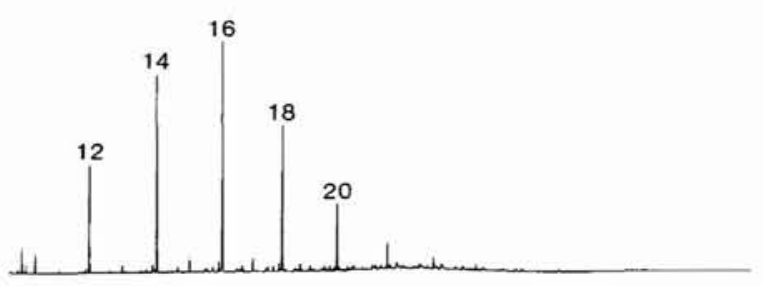

D

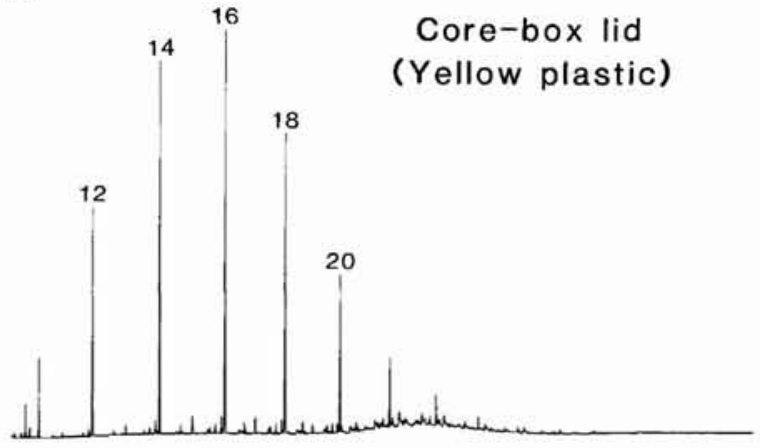

Fig. 11. Selected gas chromatograms of the saturated fraction. a: pristane, b: phytane, numbers are $n$-alkane carbon numbers. (A) Mature source rock. Sample 315855, Henson Gletscher Formation, Freuchen Land. (B) Polluted bitumen rock, note anomalously high values of $\mathrm{C}_{12}, \mathrm{C}_{14}$ and $\mathrm{C}_{16}$ n-alkanes. Sample 318003-57, Henson Gletscher Formation, Freuchen Land. (C) Extract of core-box (brown plastic). Note the high contents of $\mathrm{C}_{12}, \mathrm{C}_{14}, \mathrm{C}_{16}, \mathrm{C}_{18}$ and $\mathrm{C}_{20} n$-alkanes. (D) Extract of core-box lid (yellow plastic). Note the composition similar to the core-box. 
1/4 micron diamond powder for the final polish. Two microscope systems have been employed for measurement, in both cases using oil immersion: A reflectedlight Zeiss photomicroscope equipped with an MP03 photometer and digital readout, using a $40 \times$ Epi-pol oil immersion objective, working with a plane glass reflector. Data are collected and processed by an MPS 3000 microcomputer. A Leitz MPV-SP reflected-light microscope equipped with a pol-opak illuminator, plane glass reflector and a $32 \times$ oil immersion objective. Data are collected and processed by an MPS 3000 microcomputer.

Illumination for both systems was through a green filter with peak transmission at $546 \mathrm{~nm}$. The photomultipliers were calibrated against standards with reflectance values of 0.516 and $1.26 \% \mathrm{R}_{\mathrm{o}}{ }^{\mathrm{v}}$. Quantitative measurements of fluorescence were carried out using the Zeiss microscope system, fitted with a continuous filter monochromator and a $100 \mathrm{~W}$ high-pressure mercury lamp connected to a stabilized power supply. For UV excitation the Zeiss F1 fluorescence reflected-light illuminator is used with a $25 \times$ neofluar objective.

\section{Carbon isotope studies}

Carbon isotope measurements of kerogen, bitumen and source rock extracts were carried out at the Stable Isotope Laboratory at the Geological Institute, University of Copenhagen. This method was brought into use in the later part of the project, mainly in order to currelate observed migrated bitumens with the two main source rock units but also to provide additional information on the depositional environment.

Measurements were carried out on both kerogen and extracts of the source rock $(n=16)$ and extracts of the migrated bitumen $(n=25)$. The total extract (see previous section on GC) was employed, typically from the same samples as used in the GC, GC/MS programme. Kerogen was separated from rock samples by decalcification with $\mathrm{HCl}$ followed by methylene chloride extraction to remove bitumen and dried at $90^{\circ} \mathrm{C}$.

Combustion to $\mathrm{CO}_{2}$ (of both carbon in kerogen and in extracts) was carried out in an oxygen-helium atmosphere at $900^{\circ} \mathrm{C}$ with copper oxide as catalyst. The evolved gas was purified over copper and silver at $600^{\circ} \mathrm{C}$ and transferred to a Finngan MAT 250 triple collector mass spectrometer. The ratio between ${ }^{13} \mathrm{C}$ and ${ }^{12} \mathrm{C}$ is reported as per mille deviations from the PDB-standard using the $\delta$-function (Epstein et al., 1951). Reproducibility is better than $0.05 \%$ on the $\delta$-scale.

\section{$\mathrm{X}$-ray diffraction of kerogen}

$\mathrm{X}$-ray diffraction of kerogen concentrates was carried out at the Laboratory of Clay Mineralogy, DGU (Koch, 1987). This method, rarely applied in source rock studies, was introduced in the final stage of the working programme with the special aim of characterizing and ranking thermally postmature samples.

Fifteen organic-rich samples were prepared, eight of these represent a profile through the Cambrian-Ordovician outer shelf and slope sequence with a known systematic increase in thermal maturity. The remaining Silurian samples have a known, but highly scattered, thermal maturity.

Depending on the content of organic carbon 10-25 g of powdered sample was treated with $15 \% \mathrm{HCl}$ at a temperature of $80^{\circ} \mathrm{C}$ (see details in Koch, 1987). Following centrifugation, washing with destilled water and drying, the solid material was treated with concentrated $\mathrm{HF}$ at $80^{\circ} \mathrm{C}$ for two days and finally dried.

The kerogen concentrate was investigated by X-ray diffractometry using a Phillips 1050 vertical goniometer equipped with a graphite monochromator in the diffracted beam and using $\operatorname{CoK} \alpha$ as radiation. In addition to the kerogen study a semiquantitative evaluation of the mineral content of the samples was made. The Xray diffractogram in fig. 12 illustrates the procedure for determination of the two parameters $\mathrm{d}_{002}$ and $\mathrm{WHH}_{002}$ (position and width at half height of the 002 'graphite peak'). A number of other peaks show the presence of mineral phases (either relicts or minerals formed during preparation).

\section{Fission track studies}

Fission track studies of apatite and zircon from sandstones were carried out at the Geological Institute, University of Copenhagen. This method was included in the later part of the 'Nordolie' project in order to obtain chronological information on thermal episodes and history of uplift.

Fifteen samples representing two cross sections, one in the area where the Henson Gletscher Formation outcrops and one in the Silurian shales in Nyeboe Land, were prepared. Sample material of 0.5 to $1.5 \mathrm{~kg}$ was crushed and separated by magnetic and heavy liquid methods (see details in Hansen, 1988). The separates were mounted in epoxy or teflon, polished, and etched to reveal spontaneous tracks.

Age determinations were carried out using the external detector method (Gleadow \& Lowering, 1978) with the Fish Canyon and Mt. Dromedary apatites and zircons as age standards following the zeta calibration 

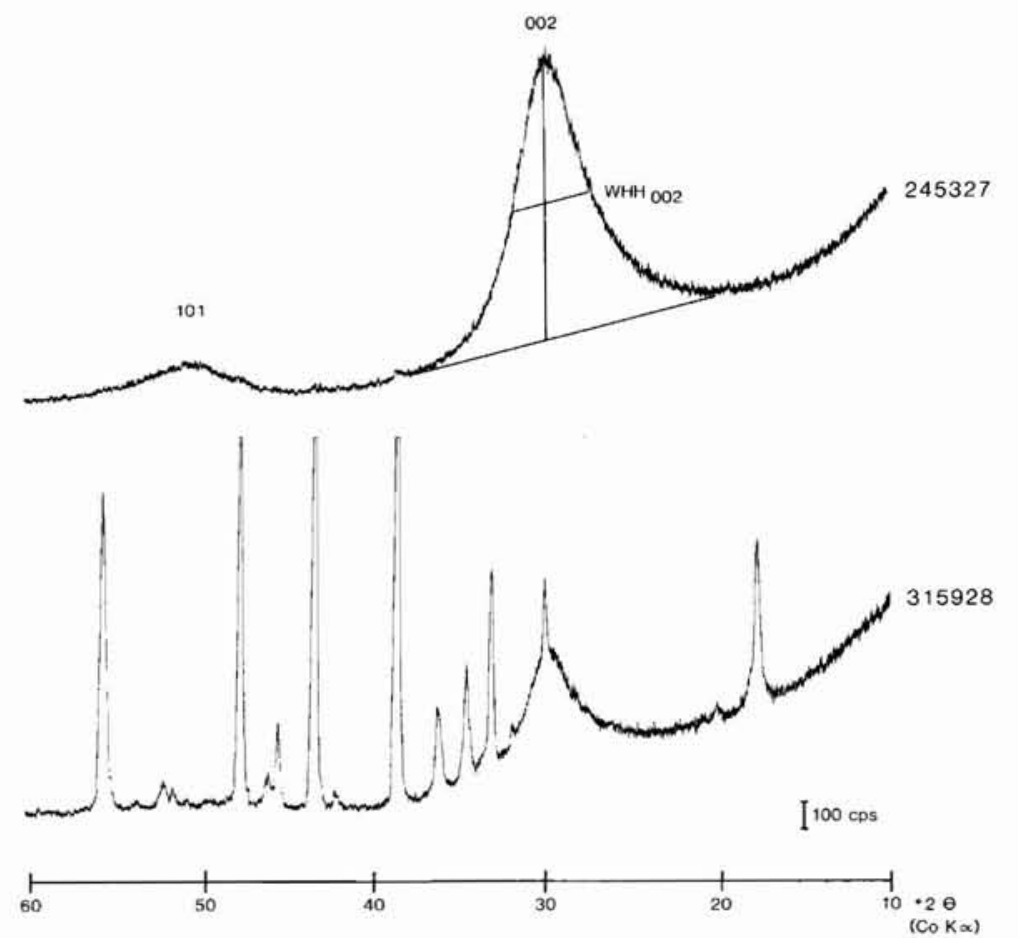

Fig. 12. X-ray diffractograms of samples 245327 and 315928 showing the procedure for determination of $\mathrm{d}_{002}$ and $\mathrm{WHH}_{002}$. The sharp peaks indicate the presence of pyrite and fluorides formed during preparation. procedure described by Hurford \& Green (1983). NBS SRM 612 and Corning $\mathrm{CN} 1$ and $\mathrm{CN} 2$ glasses were employed for monitoring the neutron fluence. The polished and etched apatites and zircons were irradiated together with high quality low-uranium mica detectors at the J1 facility of the HERALD reactor in Aldermaston, U.K., or at the Risø National Laboratory, Denmark.

All measurements for calculating the fission track length distribution in apatite were carried out on horizontal, confined tracks as suggested by Gleadow et al. (1986)

\section{Fluid inclusion studies}

Studies of fluid inclusions and stable isotopes of diagenetic calcite and dolomite associated with bitumen were carried out at the Geological Institute, Copenhagen University. These methods were employed in the later part of the project in order to obtain information on the temperature and chemistry of pore waters at the time of diagenetic growth and migration of hydrocarbons (Jensenius, 1987).

Only samples from four localities, all with macroscopically identified bitumen, were investigated.

Fluid inclusion microthermometry was performed with the aid of a Chaimeca heating and freezing stage (Poty et al., 1976) calibrated from $96^{\circ} \mathrm{C}$ to $400^{\circ} \mathrm{C}$. The stable isotopes were analysed by the following procedure at the Stable Isotope Laboratory, Geological Institute, University of Copenhagen. Approximately 30 $\mathrm{mg}$ of carbonate were crushed to a grain size between 64 and $150 \mu \mathrm{m}$, treated with sodium hypochlorite to remove migrated hydrocarbons and kerogen, followed by reaction in vacuum with concentrated $\mathrm{H}_{3} \mathrm{PO}_{4}$. The evolved $\mathrm{CO}_{2}$ was cleaned over dry ice isoproponal mixture and subsequently admitted to the Finngan Mat-250 isotope mass spectrometer.

\section{Porosity/permeability}

Measurements of the petrophysical parameters (porosity, permeability and grain density) were carried out commercially by the Core Analysis Laboratory of DGU. Approximately 60 orientated plugs $(25 \mathrm{~mm} \times 25$ $\mathrm{mm}$ ), mostly from Cambrian sandstones, were analysed. Following drying, the specific permeability is measured by flowing nitrogen through the plug. The porosity and grain density is determined applying a double chambered helium porosimeter and a picometer with calibrated mercury pump (Springer, 1987).

Thin sections of all analysed samples from the plugs or nearby slabs have been stained for carbonate identification by Dickson's method (Allman \& Lawrence, 1972) and studied in detail. 


\section{References}

Aldridge, R. J., Dorning, K. J., Hill, P. J., Richardson, J. B. \& Siveter, D. J. 1979: Microfossil distribution in the Silurian of Britain and Ireland. In Harris, A. L., Holland, C. H. \& Leake, B. E. (edit.) The Caledonides of the British Isles reviewed. Spec. Publ. geol. Soc. Lond. 8, 433-438.

Allaart, J. H. 1965: The Lower Paleozoic sediments of Hall Land, North Greenland. Unpubl. intern. GGU rep., 11 pp.

Allman, M. \& Lawrence, D. F. 1972: Geological laboratory techniques, 335 pp. London: Blandford Press.

Armstrong, H. A. \& Dorning, K. J. 1984: Silurian palynomorphs from the Chester Bjerg Formation, Hall Land, western North Greenland. Rapp. Grønlands geol. Unders. 121, 97-103.

Bally, A. W. \& Snelson, S. 1980: Reals of subsidence. Bull. Can. Petrol. Geol. 28, 9-75.

Batten, D. J. 1981: Palynofacies, organic maturation and source potential for petroleum. In Brooks, J. (edit.) Organic maturation studies and fossil fuel exploration, 201-223. London: Academic Press.

Batten, D. J. 1982: Palynology of shales associated with the Kap Washington Group volcanics, central North Greenland. Rapp. Gronland geol. Unders. 108, 15-23.

Batten, D. J. 1984: Identification of amorphous sedimentary organic matter by transmitted light microscopy. In Brooks, J. (edit.) Petroleum geochemistry and exploration of Europe. Spec. Publ. geol. Soc. Lond. 12, 275-287.

Batten, D. J., Brown, P. E., Dawes, P. R., Higgins, A. K., Koch, B. E., Parson, I. \& Soper, N. J. 1981: Peralkaline volcanicity on the Eurasia basin margin. Nature 294, 150152.

Berry, W. B. N. \& Wilde, P. 1978: Progressive ventilation of the oceans - an explanation for the distribution of the Lower Palcozoic black shales. Am. J. Sci. 278, 257-275.

Bertrand, R. \& Héroux, Y. 1987: Chitinozoan, graptolite, and scolecodont reflectance as an alternative to vitrinite and pyrobitumen reflectance in Ordovician and Silurian strata, Anticosti Island, Quebec, Canada. Bull. Am. Ass. Petrol. Geol. 71, 951-957.

Bishop, R. S., Gehman, H. M. Jr., Young, A. 1983: Concepts for estimating hydrocarbon accumulation and dispersion. Bull. Am. Ass. Petrol. Geol. 67, 337-348.

Bjerreskov, M. 1986: Silurian graptolites from N Greenland. In Hughes, C. P. \& Rickards, R. B. (edit.) Palaeoecology and biostratigraphy of graptolites. Spec. Publ. geol. Soc. Lond. 20, 181-189.

Bois, C., Bouche, P. \& Pelet, R. 1982: Global geologic history and distribution of hydrocarbon reserves. Bull. Am. Ass. Petrol. 66, 1248-1270.

Bryant, I. D. \& Smith, M. P. 1985: Lowermost Ordovician sandstones in central North Greenland. Rapp. Grønlands geol. Unders. 126, 25-30.

Buchardt, B. \& Cederberg, T. 1987: EFP-83 projekt: Stabil isotop geokemi i moderbjergarter, olie og gas i Danmark, afsluttende rapport. Geologisk Centralinstitut, København, $33 \mathrm{pp}$.
Buchardt, B., Clausen, J. \& Thomsen, E. 1986: Carbon isotope composition of Lower Palaeozoic kerogen: Effects of maturation. In Leythaeuser, D. \& Rullkötter, J. (edit.) Advances in organic geochemistry 1985. Org. Geochem. 10, 127-134.

Burgess, J. D. 1974: Microscopic examination of kerogen (dispersed organic matter) in petroleum exploration. Spec. Pap. geol. Soc. Am. 153, 19-30.

Bustin, R. M., Barnes, M. A. \& Barnes, W. C. 1985a: Diagenesis 10. Quantification and modelling of organic diagenesis. Geoscience Canada 12, 4-21.

Bustin, R. M., Cameron, A. R., Grieve, D. A. \& Kalkreuth, W. D. 1985b: Coal petrology, its principles, methods, and applications. Geol. Ass. Can. Short Course Notes 3, 230 pp.

Christiansen, F. G. (edit.) 1988: Petroleum geology of North Greenland. Final report - 'Nordolie'. Unpubl. intern. GGU rep., Part I (text) 231 pp., part II (figures) 101 pp., Appendix I (previously completed papers $43+95$ pp., Appendix II (key data) $87 \mathrm{pp}$.

Christiansen, F. G. \& Nøhr-Hansen, H. 1989: The Silurian shales of central and western North Greenland: evaluation of hydrocarbon source rock potential. Rapp. Grønlands geol. Unders. 143.

Christiansen, F. G. \& Rolle, F. 1985: Project 'Nordolie': hydrocarbon source rock investigations in central North Greenland. Rapp. Grønlands geol. Unders. 125, 17-21.

Christiansen, F. G., Nøhr-Hansen, H., Rolle, F. \& Wrang, P. 1985: Preliminary analysis of the hydrocarbon source rock potential of central and western North Greenland. Rapp. Grønlands geol. Unders. 126, 117-128.

Christiansen, F. G., Nykjær, O. \& Nøhr-Hansen, H. 1986: Source rock investigations and shallow core drilling in central and western North Greenland - project 'Nordolie'. Rapp. Grønlands geol. Unders. 130, 17-23.

Christiansen, F. G., Nøhr-Hansen, H. \& Nykjær, O. 1987: The Cambrian Henson Gletscher Formation: a mature to postmature hydrocarbon source rock sequence from North Greenland. Rapp. Grønlands geol. Unders. 133, 141-157.

Christiansen, F. G., Piasecki, S. \& Stemmerik, L. in press: Petroleum, North Greenland. In Trettin, H. P. (edit.) The Innuitian Orogen and Arctic platform: Canada and Greenland. The geology of North America E. Ottawa: Geological Survey of Canada.

Christic, R. L. 1979: The Franklinian geosyncline in the Canadian Arctic and its relationship to Svalbard. Norsk Polarinstitutt, Skrifter 167, 263-314.

Christie, R. L. \& Dawes, P. R. in press: A history of exploration and geology in the Innuitian region. In Trettin, H. P. (edit.) The Innuitian Orogen and Arctic platform: Canada and Greenland. The geology of North America E. Ottawa: Geological Survey of Canada.

Christie, R. L. \& Ineson, J. R. 1979: Precambrian-Silurian geology of the G. B. Schley Fjord region, eastern Peary Land, North Greenland. Rapp. Grønlands geol. Unders. 88, 63-71. 
Christie, R. L. \& Peel, J. S. 1977: Cambrian-Silurian stratigraphy of Børglum Elv, Peary Land, eastern North Greenland. Rapp. Grønlands geol. Unders. 82, 48 pp.

Clayton, J. L. \& Swetland, P. J. 1978: Subaerial weathering of sedimentary organic matter. Geochim. cosmochim. Acta 42, 305-312.

Clementz, D. M. 1979: Effect of oil and bitumen saturation on source rock pyrolysis. Bull. Am. Ass. Petrol. Geol. 63, 22272232.

Clemmensen, L. B. 1979: Notes on the palaeogeographical setting of the Eocambrian tillite-bearing sequence of southern Peary Land, North Greenland. Rapp. Grønlands geol. Unders. 88, 15-22.

Collinson, J. D. 1979: The Proterozoic sandstones between Heilprin Land and Mylius-Erichsen Land, eastern North Greenland. Rapp. Grønlands geol. Unders. 88, 5-10.

Collinson, J. D. 1980: Stratigraphy of the Independence Fjord Group (Proterozoic) of eastern North Greenland. Rapp. Grønlands geol. Unders. 99, 7-23.

Combaz, A. 1964: Les palynofacies. Rev. Micropaleontol. Paris 7, 205-218.

Curiale, J. A. 1986: Origin of solid bitumens, with emphasis on biological marker results. In Leythaeuser, D. \& Rullkötter, J. (edit.) Advances in organic geochemistry 1985. Org. Geochem. 10, 559-580.

Davies, W. E. 1972: Landscape of northern Greenland. Spec. Rep. Cold Reg. Res. Engng. Lab. 164, 67 pp.

Davis, N. C. \& Higgins, A. K. 1987: Cambrian - Lower Silurian stratigraphy in the fold and thrust zone between northern Nyeboe Land and J. P. Koch Fjord, North Greenland. Rapp. Grønlands geol. Unders. 133, 91-98.

Dawes, P. R. 1971: The North Greenland fold belt and environs. Bull. geol. Soc. Denmark 20, 197-239.

Dawes, P. R. 1976: Precambrian to Tertiary of northern Greenland. In Escher, A. \& Watt, W. S. (edit.) Geology of Greenland, 248-303. Copenhagen: Geol. Surv. Greenland.

Dawes, P. R. 1982: The Nyeboe Land fault zone: a major dislocation on the Greenland coast along northern Nares Strait. In Dawes, P. R. \& Kerr, J. W. (edit.) Nares Strait and the drift of Greenland: a conflict in plate tectonics. Meddr Grønland Geosci. 8, 177-192.

Dawes, P. R. 1984a: Operation Grant Land 1965-1966; a geological exploration programme in Ellesmere Island and North Greenland. Rapp. Grønlands geol. Unders. 121, 5-17.

Dawes, P. R. 1984b: Programme NordGrøn (PNG) 1983-1985: regional mapping and geological studies in western and central North Greenland. Rapp. Grønlands geol. Unders. 120 , 18-24.

Dawes, P. R. \& Christie, R. L. 1982: History of exploration and geology in the Nares Strait region. In Dawes, P. R. \& Kerr, J. W. (edit.) Nares Strait and the drift of Greenland: a conflict in plate tectonics. Meddr Grønland Geosci. 8, 19-36.

Dawes, P. R. \& Christie, R. L. in press: Geomorphic regions of the Innuitian region. In Trettin, H. P. (edit.) The Innuitian Orogen and Arctic platform: Canada and Greenland. The geology of North America E. Ottawa: Geological Survey of Canada.
Dawes, P. R. \& Haller, J. 1979: Historical aspects in the geological investigation of northern Greenland. Part 1: New maps and photographs from the 2nd Thule Expedition 1916-18 and the Bicentenary Jubilee Expedition 1920-1923. Meddr Grønland 200(4), 38 pp.

Dawes, P. R. \& Kerr, J. W. (edit.) 1982: Nares Strait and the drift of Greenland: a conflict in plate tectonics. Meddr Grønland Geosci. 8, 392 pp.

Dawes, P. R. \& Peel, J. S. 1981: The northern margin of Greenland from Baffin Bay to the Greenland Sea. In Nairn, A. E. M., Churkin, M. \& Stehli, F. G. (edit.) The ocean basins and margins 5, 201-264. New York: Plenum Publ. Corp.

Dawes, P. R. \& Soper, N. J. 1970: Geological investigations in northern Peary Land. Rapp. Grønlands geol. Unders. 28, 9-15.

Dawes, P. R. \& Soper, N. J. 1973: Pre-Quaternary history of North Greenland. In Pitcher, M. G. (edit.) Arctic geology. Mem. Am. Ass. Petrol. Geol. 19, 117-134.

Dawes, P. R. \& Soper, N. J. 1979: Structural and stratigraphic framework of the North Greenland fold belt in Johannes V. Jensen Land, Peary Land. Rapp. Grønlands geol. Unders. 93, $40 \mathrm{pp}$.

Dawes, P. R. \& Soper, N. J. 1973: Pre-Quaternary history of North Greenland. In Pitcher, M. G. (edit.) Arctic geology. Mem. Am. Ass. Petrol. Geol. 19, 117-134.

W. (edit.) Nares Strait and the drift of Greenland: a conflict in plate tectonics. Meddr Grønland Geosci. 8, 89-104.

Deines, P. 1980: The isotopic composition of reduced organic matter. In Fritz, P. \& Fontez, J. Ch. (edit.) Handbook of environmental isotope geochemistry. Vol. 1, The terrestrial environment, 329-407. Amsterdam: Elsevier.

Demaison, G. 1984: The generative basin concept. In Demaison, G. \& Murris, R. J. (edit.) Petroleum geochemistry and basin evaluation. Mem. Am. Ass. Petrol. Geol. 35, 1-14.

Dorning, K. J. 1987: The organic palaeontology of Palaeozoic carbonate environments. In Hart, M. B. (edit.) Micropalaeontology of carbonate environments, 256-265. Chichester, England: Ellis Horwood Ltd.

Dow, W. G. 1977: Kerogen studies and geological interpretations. J. geochem. Expl. 7, 79-99.

Duffield, S. L. 1985: Land-derived microfossils from the Jupiter Formation (Upper Llandoverian) Anticosta Island, Québec. J. Paleont. 59, 1005-1010.

Durand, B. (edit.) 1980: Kerogen. Insoluble organic matter from sedimentary rocks, 519 pp. Paris: Editions Technip.

Ellitsgaard-Rasmussen, K. 1955: Features of the geology of the folding range of Peary Land, North Greenland. Meddr Grønland 127(7), $56 \mathrm{pp}$.

Embry, A. F., Powell, T. C. \& Mayr, U. in press: Petroleum resources, Arctic Islands. A. Petroleum. In Trettin, H. P. (edit.) The Innuitian Orogen and Arctic platform: Canada and Greenland. The geology of North America E. Ottawa: Geological Survey of Canada.

Epstein, A. G., Epstein, J. B. \& Harris, L. D. 1977: Conodont color alteration - an index to metamorphism. Prof. Pap. U.S. geol. Surv. 995, 27 pp. 
Epstein, S., Buchsbaum, R., Lowenstam, H. A. \& Urey, H. C. 1951: Carbonate-water isotopic temperature scale. Bull. geol. Soc. Am. 62, 417-425.

Escher, J. C. \& Larsen P.-H. 1987: The buried western extension of the Navarana Fjord escarpment in central and western North Greenland. Rapp. Gronlands geol. Unders. 133, 81-89.

Espitalié, J., Laporte, J. L., Madec, M., Marquis, F., Leplat, P. 1977: Methode rapide de caracterisation des roches mères de leur potentiel pétrolier et de leur degré d'évolution. Revue Inst. fr. Pétrole 32, 23-42.

Espitalié, J., Madec, M. \& Tissot, B. 1980: Role of mineral matrix in kerogen pyrolysis: influence on petroleum generation and migration. Bull. Am. Ass. Petrol. Geol. 64, 59-66.

Espatilié, J., Makadi, K. S. \& Trichet, Y. 1984: Role of the mineral matrix during kerogen pyrolysis. Org. Geochem. 6, 365-382.

Evans, R. J. \& Felbeck, Jr. G. T. 1983: High temperature simulation of petroleum formation - II. Effects of inorganic sedimentary constituents on hydrocarbon formation. Org. Geochem. 4, 145-152.

Folk, R. L. 1968: Petrology of sedimentary rocks, 170 pp. Austin, Texas: Hemphill's.

Forsberg, A. \& Bjorøy, M. 1983: A sedimentological and organic geochemical study of the Botneheia Formation, Svalbard, with special emphasis on the effects of weathering on the organic matter in shales. In Bjorøy, M. et al. (edit.) Advances in organic geochemistry 1981, 60-68. London: Wiley \& sons Ltd.

Foscolos, A. E., Powell, T. G. \& Gunther, P. R. 1976: The use of clay minerals and inorganic and organic geochemical indicators for evaluating the degrec of diagenesis and oil generating potential of shales. Geochim. cosmochim. Acta $\mathbf{4 0}$, 953-966.

Friderichsen, J. D. \& Bengaard, H.-J. 1985: The North Greenland fold belt in eastern Nansen Land. Rapp. Grønlands geol. Unders. 126, 69-78.

Friderichsen, J. D., Higgins, A. K., Hurst, J. M., Pedersen, S. A. S., Soper, N. J. \& Surlyk, F. 1982: Lithostratigraphic framework of the Upper Proterozoic and Lower Palaeozoic deep water clastic deposits of North Greenland. Rapp. Gronlands geol. Unders. 107, $20 \mathrm{pp}$.

Frisch, T. 1974: Metamorphic and plutonic rocks of northernmost Ellesmere Island, Canadian Arctic Archipelago. Bull. geol. Surv. Can. 229, 87 pp.

Galimov, E. M. 1980: ${ }^{13} \mathrm{C} /{ }^{12} \mathrm{C}$ in kerogen. In Durand, B. (edit.) Kerogen, 271-300. Paris: Editions Technip.

Gleadow, A. J. W. \& Lovering, J. F. 1978: Thermal history of granitic rocks from western Victoria: a fission track dating study. J. Geol. Soc. Aust. 25, 323-340.

Gleadow, A. J. W., Duddy, I. R. \& Lovering, J. F. 1983: Fission track analysis: a new tool for the evaluation of thermal histories and hydrocarbon potential. Austr. Petrol. Expl. Assoc. J. 23, 93-102.

Gleadow, A. J. W., Duddy, I. R., Green, P. F. \& Lovering, J. F. 1986: Confined fission track lengths in apatite: a diagnostic tool for thermal history. Contr. Mineral. Petrol. 94, $405-415$.
Glensen, P. G. \& Andrews, H. N. 1987: The evolution of early land plants. American Scientist 75, 478-489.

Glickson, M., Gibson, D. L. \& Philp, R. P. 1985: Organic matter in Australian Cambrian oil shales and Lower Palaeozoic shales. Chem. Geol. 51, 175-191.

Goodarzi, F. \& Norford, B. S. 1985: Graptolites as indicators of the temperature history of rocks. J. geol. Soc. Lond. 142, 1089-1099.

Goodarzi, F., Snowdon, L. R., Gunther, P. R. \& Jenkins, W. A. M. 1985: Preliminary organic petrography of Palaeozoic rocks from the Grand Banks, Newfoundland. Marine Petrol. Geol. 2, 254-259.

Grahn, Y. \& Nøhr-Hansen, H. 1989: Chitinozoans from Ordovician and Silurian shelf and slope sequences from North Greenland. Rapp. Grønlands geol. Unders. 144.

Grantham, P. J. 1986: The occurrence of unusual $C_{27}$ and $C_{29}$ sterane predominance in two types of Oman crude oil. Org. Geochem. 9, 1-10.

Grønlands Fiskeri- og Miljøundersøgelser 1986: Biologiske miljøundersøgelser i Nordgrønland 1984-85. Unpubl. rep., 113 pp.

Gutjahr, C. C. M. 1983: Introduction to incident-light microscopy of oil and gas source rocks. Geol. Mijnbouw 62, 417425 .

Håkansson, E. \& Stemmerik, L. 1984: Wandel Sea Basin-The North Greenland equivalent to Svalbard and the Barents Shelf. In Spencer, A. M. et al. (edit.) Petroleum geology of North European margin, 97-107. Norwegian Petroleum Society.

Hansen, B. T., Kalsbeek, F. \& Holm, P. M. 1987: Archaean age and Proterozoic metamorphic overprinting of the crystalline basement at Victoria Fjord, North Greenland. Rapp. Grønlands geol. Unders. 133, 159-168.

Hansen, K. 1985: Fission track age determinations of vertical movements in the crust caused by continental rifting: a fission track age study of the Scoresby Sund area; method and results. Unpublished lic.scient. thesis, Univ. Copenhagen, 119 pp.

Hatch, J. R., Jacobsen, S. R., Witzke, B. J., Risatti, J. B., Anders, D. E., Watney, W. L., Newell, K. D. \& Vuletich, A. K. 1987: Possible late Middle Ordovician organic carbon isotope excursion: evidence from Ordovician oils and hydrocarbon source rocks, Mid-Continent and East-Central United States. Bull. Am. Ass. Petrol. Geol. 71, 1342-1354.

Henderson, G. 1976: Petroleum geology. In Escher, A. \& Watt, W. S. (edit.) Geology of Greenland, 489-505. Copenhagen: Geol. Surv. Greenland.

Henriksen, N. 1985a: Systematic 1:500 000 mapping and regional geological studies in central and western North Greenland. Rapp. Grønlands geol. Unders. 125, 9-17.

Henriksen, N. 1985b: Systematic geological mapping in 1984 in central and western North Greenland. Rapp. Grønlands geol. Unders. 126, 5-10.

Henriksen, N. 1986: Completion of field work for the 1:500 000 mapping and regional geological studies in central and western North Greenland. Rapp. Gronlands geol. Unders. 130, 9-17.

Henriksen, N. 1987: Systematic geological mapping in 1985 in 
central and western North Greenland. Rapp. Grønlands geol. Unders. 133, 5-12.

Henriksen, N. \& Jepsen, H. F. 1985: Precambrian crystalline basement at the head of Victoria Fjord, North Greenland. Rapp. Grønlands geol. Unders. 126, 11-16.

Henriksen, N. \& Peel, J. S. 1976: Cambrian - Early Ordovician stratigraphy in southwestern Washington Land, western North Greenland. Rapp. Grønlands geol. Unders. 80, 17-23.

Heroux, Y. Chagnon, A. \& Bertrand, R. 1979: Compilation and correlation of major thermal maturation indicators. Bull. Am. Ass. Petrol. Geol. 63, 2128-2144.

Higgins, A. K. 1986: Geology of central and eastern North Greenland. Rapp. Grønlands geol. Unders. 128, 37-54.

Higgins, A. K. \& Soper, D. J. 1985: Cambrian - Lower Silurian slope and basin stratigraphy between northern Nyeboe Land and western Amundsen Land, North Greenland. Rapp. Grønlands geol. Unders. 126, 79-86.

Higgins, A. K., Mayr, U. \& Soper, N. J. 1982: Fold belts and metamorphic zones of northern Ellesmere Island and North Greenland. Rapp. Grønlands geol. Unders. 130, 9-17.

Higgins, A. K., Soper, N. J. \& Friderichsen, J. D. 1985: North Greenland fold belt in eastern North Greenland. In Gee, D. G. \& Sturt, B. A. (edit.) The Caledonide Orogen - Scandinavia and related areas, 1017-1029. London: John Wiley \& Sons Ltd.

Higgins, A. K., Ineson, J. R., Peel, J. S., Surlyk, F. \& Sønderholm, M. in press: The Franklinian basin in North Greenland. In Trettin, H. P. (edit.) The Innuitian Orogen and Arctic platform: Canada and Greenland. The geology of North America E. Ottawa: Geological Survey of Canada.

Hills, I. R., Whitehead, E. V., Anders, D. E., Cummins, J. J. \& Robinson, W.E. 1966: An optically active triterpane, gammacerane in Green River, Colorado, oil shale bitumen. Chem. Commun. 20, 752-754.

Horsfield, B. 1984: Pyrolysis studies and petroleum exploration. In Brooks, J. \& Welte, D. (edit.) Advances in petroleum geochemistry 1, 247-298. London: Academic Press.

Horsfield, B., Dembicki Jr, H. \& Ho, T. T. Y. 1983: Some potential applications of pyrolysis to basin studies. J. geol. Soc. Lond. 140, 431-443.

Huang, W.-Y. \& Meinschein, W. G. 1976: Sterols as ecological indicators. Geochim. cosmochim. Acta 40, 323-330.

Hunt, J. M. 1979: Petroleum geochemistry and geology, 615 pp. San Francisco: W. H. Freeman and Co.

Hurford, A. J. 1986: Cooling and uplift patterns in the Lepontine Alps, South Central Switzerland and an age of the vertical movement on the Insubric fault line. Contrib. Miner. Petrol. 92, 413-427.

Hurford, A. J. \& Green, P. F. 1983: The zeta age calibration of fission track dating. Isotope Geosci. 1, 285-317.

Hurst, J. M. 1980a: Silurian stratigraphy and facies distribution in Washington Land and western Hall Land, North Greenland. Bull. Grønlands geol. Unders. 138, 95 pp.

Hurst, J. M. 1980b: Paleogeographic and stratigraphic differentiation of Silurian buildups and biostromes of North Greenland. Bull. Am. Ass. Petrol. Geol. 64, 527-548.

Hurst, J. M. 1981: Platform edge and slope relationships:
Silurian of Washington Land, North Greenland and comparison to Arctic Canada. Bull. Can. Petrol. Geol. 29, 408-419.

Hurst, J. M. 1984: Upper Ordovician and Silurian carbonate shelf stratigraphy, facies and evolution, eastern North Greenland. Bull. Grønlands geol. Unders. 148, 73 pp.

Hurst, J. M. \& Peel, J. S. 1979: Late Proterozoic (?) to Silurian stratigraphy of southern Wulff Land, North Greenland. Rapp. Grønlands geol. Unders. 91, 37-56.

Hurst, J. M. \& Surlyk, F. 1982: Stratigraphy of the Silurian turbidite sequence of North Greenland. Bull. Grønlands geol. Unders. 145, $121 \mathrm{pp}$.

Hurst, J. M. \& Surlyk, F. 1983: Initiation, evolution and destruction of an early Paleozoic carbonate shelf, eastern North Greenland. J. Geol. 91, 671-691.

Hurst, J. M., McKerrow, W. S., Soper, N. J. \& Surlyk, F. 1983: The relationship between Caledonian nappe tectonics and Silurian turbidite deposition in North Greenland. $J$. geol. Soc. Lond. 140, 123-132.

Illich, H. A. 1983: Pristane, phytane, and lower molecular weight isoprenoid distributions in oils. Bull. Am. Ass. Petrol. Geol. 67, 385-397.

Ineson, J. R. 1985: The stratigraphy and sedimentology of the Brønlund Fjord and Tavsen Iskappe Groups (Cambrian) of Peary Land, eastern North Greenland. Unpublished Ph.D. thesis, University of Keele, U.K., $310 \mathrm{pp}$.

Ineson, J. R. \& Peel, J. S. 1980: Cambrian stratigraphy in Peary Land, eastern North Greenland. Rapp. Gronlands geol. Unders. 99, $33-42$.

Ineson, J. R. \& Peel, J. S. 1987: Cambrian platform - outer shelf relationship in the Nordenskiöld Fjord region, central North Greenland. Rapp. Grønlands geol. Unders. 133, 13-26.

Ineson, J. R. \& Peel, J. S. in press: Cambrian shelf stratigraphy of the Peary Land region, central North Greenland. Bull. Grønlands geol. Unders.

Jacob, H. 1983: Recent studies on the genesis of natural solid oil bitumens. Geol. Jahr. Reihe D 59,61 pp.

Jacob, H. 1985: Disperse, feste Erdölbitumina als Migrationsund Maturitätsindikatoren im Rahmen der Erdöl-/ErdgasProspektion. Eine Modellstudie in NW-Deutschland. Deutsche Gesellschaft Mineralölwissenschaft und Kohlechemie E.V., Forschungsbericht 267, $54 \mathrm{pp}$.

Jensenius, J. 1987: Fluid inclusion and stable isotope studies of diagenctic calcite and dolomite associated with seeping asphalt, North Greenland, 28 pp. In Jensenius, J. 1987: Fluid inclusion microthermometry and stable isotope studies applied to the diagenesis of sedimentary rocks. Unpublished lic. scient. thesis, University of Copenhagen.

Jepsen, H. F. 1971: The Precambrian, Eocambrian and early Palaezoic stratigraphy of the Jørgen Brønlund Fjord area, Peary Land, North Greenland. Bull. Grønlands geol. Unders. 96, 42 pp.

Jones, R. W. 1987: Organic facies. In Brooks, J. (edit.) Advances in petroleum geochemistry 2, 1-90. London: Academic Press.

Katz, B. J. 1983: Limitations of 'Rock-Eval' pyrolysis for typing organic matter. Org. Geochem. 4, 195-199.

Kerr, J. W. 1967: Nares submarine rift valley and relative 
rotation of North Greenland. Bull. Can. Petrol. Geol. 15, 483-520.

Kerr, J. W. 1980: A plate tectonic contest in Arctic Canada. In Strangway, D. W. (edit.) The continental crust and its mineral deposits. Spec. Pap. geol. Ass. Can. 20, 457-486.

Kingston, D. R., Dishroon, C. P. \& Williams, P. A. 1985: Global basin classification system. Oil Gas J. 83(18), 238262.

Kisch, H. J. 1980: Incipient metamorphism of Cambro-Silurian clastic rocks from the Jamtland Supergroup, central Scandinavian caledonides, western Sweden: illite crystallinite and 'vitrinite' reflectance. J. geol. Soc. Lond. 137, 271-288.

Klemme, H. D. 1971: What giants and their basins have in common. Oil Gas J. 69(9), 85-90.

Koch, C. J. W. 1987: Preparation and characterization by $\mathrm{X}$-ray diffraction of kerogen from Cambrian and Silurian sedimentary rocks from North Greenland. Unpubl. intern. GGU rep., 13 pp.

Koch, L. 1925: The geology of North Greenland. Am. J. Sci. 9, 271-285.

Koch, L. 1929: Stratigraphy of Greenland. Meddr Grønland 73(2), 205-320.

Kontorovich, A. E. 1984: Geochemical methods for the quantitative evaluation of the petroleum potential of sedimentary basins. In Demaison, G. \& Murris, R. J. (edit.) Petroleum geochemistry and basin evaluation. Mem. Am. Ass. Petrol. Geol. 35, 79-109.

Krebs, W. \& Macqueen, R. W. 1984: Sequence of diagenetic and mineralization events, Pine-Point lead-zinc property, Northwest Territories, Canada. Bull. Can. Petrol. Geol. 32, 434-464.

Larsen, N. H. 1985: Cambrian endolithic alga from North Greenland. Sec. Int. Phycol. Congr., Book of abstracts, 88. Copenhagen.

Larsen, N. H. 1989: Fossil algae from North Greenland. Open File Ser. Grønlands geol. Unders. 89/3, 32 pp. +42 figs.

Larsen, O. 1982: The age of the Kap Washington Group volcanics, North Greenland. Bull. geol. Soc. Denmark 31, 49-55.

Larsen, O., Dawes, P. R. \& Soper, N. J. 1978: Rb/Sr age of the Kap Washington Group, Peary Land, North Greenland, and its geotectonic implications. Rapp. Grønlands geol. Unders. 90, 115-119.

Larsen, P.-H. \& Escher, J. C. 1985: The Silurian turbidite sequence of the Peary Land Group between Newman Bugt and Victoria Fjord, western North Greenland. Rapp. Grønlands geol. Unders. 126, 47-67.

Larsen, P.-H. \& Escher, J. C. 1987: Additions to the lithostratigraphy of the Peary Land Group (Silurian) in western and central North Greenland. Rapp. Gronlands geol. Unders. 133, 65-80.

Larsen, P.-H., Edwards, D. \& Escher, J. C. 1987: Late Silurian plant megafossils from the Peary Land Group, North Greenland. Rapp. Grønlands geol. Unders. 133, 107-112.

Legall, F. D., Barnes, C. R. \& Macqueen, R. W. 1981: Thermal maturation, burial history and hotspot development, Paleozoic strata of southern Ontario-Québec, from cono- dont and acritarch colour alteration studies. Bull. Can. Petrol. Geol. 29, 492-539.

Leggett, J. K., McKerrow, W. S., Cocks, L. R. M. \& Richards, R. B. 1981: Perodicity in the early Palaeozoic marine realm. J. geol. Soc. Lond. 138, 167-176.

Lewan, M. D. 1983: Effects of thermal maturation on stable organic carbon isotopes as determined by hydrous pyrolysis of Woodford Shale. Geochim. cosmochim. Acta 47, 14711479.

Lewan, M. D. 1986: Stable carbon isotopes of amorphous kerogens from Phanerozoic rocks. Geochim. cosmochim. Acta 50, 1583-1591.

Leythaeuser, D. 1973: Effects of weathering on organic matter in shales. Geochim. cosmochim. Acta 37, 113-120.

Link, W. K. 1952: Significance of oil and gas seeps in World oil exploration. Bull. Am. Ass. Petrol. Geol. 36, 1505-1540.

Macauley, G., Snowdon, L. R. \& Ball, F. D. 1985: Geochemistry and geological factors governing exploitation of selected Canadian oil shale deposits. Pap. geol. Surv. Can. 85-13, 65 pp.

Mackenzie, A. G. 1984: Applications of biological markers in petroleum geochemistry. In Brooks, J. \& Welte, D. H. (edit.) Advances in petroleum geochemistry 1, 115-214. London: Academic Press.

Macqueen, R. W. \& Powell, T. G. 1983: Organic geochemistry of the Pine Point lead-zinc ore field and region, Northwest Territories, Canada. Econ. Geol. 78, 1-15.

Marcussen, C., Christiansen, F. G., Larsen, P.-H., Olsen, H., Piasecki, S., Stemmerik, L., Bojesen-Koefoed, J., Jepsen, H. F. \& Nøhr-Hansen, H. 1987: Studies of the onshore hydrocarbon potential in East Greenland 1986-87: field work from $72^{\circ}$ to $74^{\circ} \mathrm{N}$. Rapp. Grønlands geol. Unders. 135, 72-81.

McKerrow, W. S. 1979: Ordovician and Silurian changes in sea level. J. geol. Soc. Lond. 136, 137-145.

McKirdy, D. M., Aldridge, A. K. \& Ypma, P. J. M. 1983: A geochemical comparison of some crude oils from Pre-Ordovician carbonate rocks. In Bjoroy, M. et al. (edit.) Advances in organic geochemistry 1981, 99-107. London: Wiley \& Sons Ltd.

McKirdy, D. M., Kantsler, A. J., Emmett, J. K. \& Aldridge, A. K. 1984: Hydrocarbon genesis and organic facies in Cambrian carbonates of the eastern Officer basin, South Australia. In Palacas, J. G. (edit.) Petroleum geochemistry and source rock potential of carbonate rocks. Am. Ass. Petrol. Geol. Stud. Geol. 18, 13-31.

Miller, B. M. 1986: Resource appraisal methods, choice and outcome. In Rice, D. D. (edit.) Oil and gas assessment. Am. Ass. Petrol. Geol. Stud. Geol. 21, 1-23.

Moldowan, J. M. Seifert, W. K. \& Gallegos, E. J. 1985: Relationship between petroleum composition and depositional environment of petroleum source rocks. Bull. Am. Ass. Petrol. Geol. 69, 1255-1268.

Moore, L. V. 1984: Significance, classification of asphaltic material in petroleum exploration. Oil Gas J. 82(41), 109 112 .

Nassichuk, W. W. 1983: Petroleum potential in Arctic North 
America and Greenland. Cold Regions Science and Technology 7, 51-88.

Nielsen, E. 1941: Remarks on the map and the geology of Kronprins Christians Land. Meddr Grønland 126(2), 34 pp.

Norford, B. S. 1972: Silurian stratigraphic sections at Kap Tyson, Offley $\emptyset$ and Kap Schuchert, northwestern Greenland. Meddr Grønland 195(2), 40 pp.

Nøhr-Hansen, H. \& Koppelhus, E. B. 1988: Ordovician spores with trilete rays from Washington Land, North Greenland. Rev. Palaeobot. Palynol. 56, 305-311.

O'Connor, B. 1979: The Portfjeld Formation (?early Cambrian) of eastern North Greenland. Rapp. Grønlands geol. Unders. 88, 23-28.

Ogunyami, O., Hesse, R. \& Héroux, Y. 1980: Pre-orogenic and synorogenic diagenesis and anchimetamorphism in Lower Paleozoic continental margin sequences of the northern Appalachians in and around Quebec City, Canada. Bull. Can. Petrol. Geol. 28, 559-577.

Ourisson, G., Albrecht, P. \& Rohmer, M. 1979: Paleochemistry and biochemistry of a group of natural products: the hopanoids. Pure Appl. Chem. 51, 709-729.

Østfeldt, P. 1987a: Oil-source rock correlation in the Danish North Sea. In Brooks, J. \& Glennie, K. (edit.): Petroleum geology of North West Europe, 419-429. London: Graham \& Trotman.

Østfeldt, P. 1987b: Organic geochemistry of North Greenland samples. Unpubl. intern. GGU rep., 43 pp.

Parrish, J. T. 1982: Upwelling and petroleum source beds, with reference to Paleozoic. Bull. Am. Ass. Petrol. Geol. 66, $750-774$.

Parrish, J. T. 1987: Palaeo-upwelling and the distribution of organic-rich rocks. In Brooks, J. \& Fleet, A. J. (edit.) Marine petroleum source rocks. Spec. Publ. geol. Soc. Lond. 26, 199-205.

Peel, J. S. 1979: Cambrian-Middle Ordovician stratigraphy of the Adams Gletscher region, south-west Peary Land, North Greenland. Rapp. Grønlands geol. Unders. 88, 29-39.

Peel, J. S. 1980: Cambrian and Ordovician geology of Warming Land and southern Wulff Land, central North Greenland. Rapp. Grønlands geol. Unders. 101, 55-60.

Peel, J. S. 1982: The Lower Paleozoic of Greenland. In Embry, A. F. \& Balkwill, H. R. (edit.) Arctic geology and geophysics. Mem. Can. Soc. Petrol. Geol. 8, 309-330.

Peel, J. S. 1985: Cambrian - Silurian platform stratigraphy of eastern North Greenland. In Gee, D. G. \& Sturt, B. A. (edit.) The Caledonide Orogen - Scandinavia and related areas, 1077-1094. London: John Wiley \& Sons Ltd.

Peel, J. S. \& Christie, R. L. 1982: Cambrian-Ordovician stratigraphy, correlations around Kane basin. In Dawes, P. R. \& Kerr, J. W. (edit.) Nares Strait and the drift of Greenland: a conflict in plate tectonics. Meddr Grønland Geosci. 8, 117135.

Peel, J. S. \& Hurst, J. M. 1980: Late Ordovician and early Silurian stratigraphy of Washington Land, western North Greenland. Rapp. Gronlands geol. Unders. 100, 18-24.

Peel, J. S. \& Wright, S. C. 1985: Cambrian platform stratigraphy in the Warming Land - Freuchen Land region, North Greenland. Rapp. Grønlands geol. Unders. 126, 17-24.
Peel, J. S., Dawes, P. R., Collinson, J. D. \& Christie, R.L. 1982: Proterozoic - basal Cambrian stratigraphy across Nares Strait: correlation between Inglefield Land and Bache Peninsula. In Dawes, P. R. \& Kerr, J. W. (edit.) Nares Strait and the drift of Greenland: a conflict in plate tectonics. Meddr Grønland Geosci. 8, 105-115.

Perregaard, J. 1979: Organic geochemistry of sedimentary organic matter from Greenland: a petroleum source rock evaluation. Unpubl. intern. GGU rep., 81 pp. + appendix.

Philp, R. P. \& Lewis, C. A. 1987: Organic geochemistry of biomarkers. Ann. Rev. Earth Planet. Sci. 15, 363-395.

Poty, B., Leroy, J. \& Jachimowicz, 1976: A new device for measuring temperatures under microscope: the Chaixmeca microthermometry apparatus. In Roedder, E. \& Kozlowski, A. (edit) Fluid inclusion research 9, 173-178.

Powell, T. G. 1978: An assessment of the hydrocarbon source potential of the Canadian Arctic Island. Pap. geol. Surv. Can. 78-12, 82 pp.

Powell, T. G., Macqueen, R. W., Barker, J. F. \& Bree, D. G. 1984: Geochemical character and origin of Ontario oils. Bull. Can. Petrol. Geol. 32, 289-312.

Procter, R. M., Tayor, G. C. \& Wade, J. A. 1984: Oil and gas resources of Canada. Pap. geol. Surv. Can. 83-31, 59 pp.

Radke, B. M. \& Mathis, R. L. 1980: On the formation and occurrence of saddle dolomite. J. sed. Petrol. 50, 1149-1168.

Rayer, F. G. 1981: Exploration prospects and future petroleum potential of the Canadian Arctic Islands. J. petrol. Geol. 3, $367-412$.

Reed, J. D., Illich, H. A. \& Horsfield, B. 1986: Biochemical evolutionary significance of Ordovician oils and their sources. In Leythaeuser, D. \& Rullkötter, J. (edit.) Advances in organic geochemistry 1985. Org. Geochem. 10, 347-358.

Rice, D. D. (edit.) 1986: Oil and gas assessment. Am. Ass. Petrol. Geol. Stud. Geol. 21, 267 pp.

Robert, P. 1974: Analyse microscopique des charbons et des bitumen dispersés dans roches et mesure de leur pouvoir réflecteur. Application à l'étude de la paléogéothermie des bassins sédimentaires et de la genèse des hydrocarbures. In Tissot, B. \& Bienner, F. (edit.) Advanced organic geochemistry, 549-569. Rueil-Malmaison.

Rogers, M. A., McAlary, J. D. \& Baily, N. J. L. 1974: Significance of reservoir bitumens to thermal-maturation studies, Western Canada basin. Bull. Am. Ass. Petrol. Geol. 58, 1806-1824.

Rolle, F. 1981: Hydrocarbon source rock sampling in Peary Land 1980. Rapp. Grønlands geol. Unders. 106, 99-103.

Rolle, F. \& Wrang, P. 1981: En foreløbig oliegeologisk vurdering af Peary Land området i Nordgrønland. Unpubl. intern. GGU rep., 21 pp.

Rullkötter, J., Meyers, P. A., Schaefer, R. G. \& Dunham, K. W. 1986: Oil generation in the Michigan Basin: a biological marker and carbon isotope approach. In Leythaeuser, D. \& Rullkötter, J. (edit.) Advances in organic geochemistry 1985. Org. Geochem. 10, 359-375.

St. John, B., Bally, A. W. \& Klemme, H. D. 1984: Sedimentary provinces of the world - hydrocarbon productive 
and nonproductive. Am. Assoc. Petrol. Geol. Map Library, 36 pp. + maps.

Schoell, M. 1984: Wasserstoff- und Kohlenstoffisotope in organischen Substanzen, Erdölen und Erdgassen. Geol Jahrb. Reihe D. 67, 167 pp.

Schopf, T. J. M. 1983: Paleozoic black shales in relation to continental margin upwelling. In Thiede, J. \& Suess, E. (edit.) Coastal upwelling, its sediment record, part B: Sedimentary records of ancient coastal upwelling, 570-596. New York: Plenum Press.

Scotese, C. R., Bambach, R. K., Barton, C., Van der Voo, R. \& Ziegler, A. M. 1979: Palaeozoic base maps. J. Geol. 87 , 217-278.

Sikander, A. H. \& Pittion, J. L. 1978: Reflectance studies on organic matter in Lower Paleozoic sediments of Quebec. Bull. Can. Petrol. Geol. 26, 132-151.

Sluijk, D. \& Nederlof, M. H. 1984: Worldwide geological experience as a systematic basis for prospect appraisal. In Demaison, G. \& Murris, R. J. (edit.) Petroleum geochemistry and basin evaluation. Mem. Am. Ass. Petrol. Geol. 35, 15-26.

Smith, M. P., Sønderholm, M. \& Tull, S. J. 1989: The Morris Bugt Group (Middle Ordovician - Early Silurian) of North Greenland and its correlatives. Rapp. Grønlands geol. Unders. 143.

Sønderholm, M. \& Due, P. H. 1985: Lower and Middle Ordovician platform carbonate lithostratigraphy of Warming Land, Wulff Land and Nares Land, North Greenland. Rapp. Grønlands geol. Unders. 126, 31-46.

Sønderholm, M. \& Harland, T. L. 1989a: Franklinian reef belt, Silurian, North Greenland. In Geldsetzer, H. J. J., James, N. P. \& Tebbutt, G. E. (edit.) Reefs, Canada and adjacent area. Mem. Can. Soc. Petrol. Geol. 13, 356-366.

Sønderholm, M. \& Harland, T. L. 1989b: Latest Ordovicianearliest Silurian reef mounds in western North Greenland. In Geldsetzer, H. J. J., James, N. P. \& Tebbutt, G. E. (edit.) Reefs, Canada and adjacent area. Mem. Can. Soc. Petrol. Geol. 13, 241-243.

Sønderholm, M., Harland, T. L., Due, P. H., Jørgensen, L. N. \& Peel, J. S. 1987: Lithostratigraphy and depositional history of Upper Ordovician - Silurian shelf carbonates in central and western North Greenland. Rapp. Grønlands geol. Unders. 133, 27-40.

Soper, N. J. \& Higgins, A. K. 1987: A shallow detachment beneath the North Greenland fold belt: implications for sedimentation and tectonics. Geol. Mag. 124, 441-450.

Soper, N. J., Dawes, P. R. \& Higgins, A. K. 1982: CretaceousTertiary magmatic and tectonic events in North Greenland and the history of adjacent ocean basins. In Dawes, P. R. \& Kerr, J. W. (edit.) Nares Strait and the drift of Greenland: a conflict in plate tectonics. Meddr Grønland Geosci. 8, 205220.

Springer, N. 1981: Preliminary Rb-Sr age determinations from the North Greenland fold belt, Johannes V. Jensen Land, with comments on the metamorphic grade. Rapp. Grønlands geol. Unders. 106, 77-84.

Springer, N. (compiler) 1987: Conventional core analysis for
GGU. Cambrian sandstones from North Greenland (Nordolie). Unpubl. intern. GGU rep., 17 pp.

Sproule, J. C. 1966: Oil and gas prospects of the Canadian Arctic Islands. Proc. 8th Commonwealth Mining and Metallurgical Congress, Australia and New Zealand 1965, Vol. 5 (Petroleum), 57-64.

Staplin, F. L. 1969: Sedimentary organic matter, organic metamorphism, and oil and gas occurrence. Bull. Can. Soc. Petrol. Geol. 17, 47-66.

Stemmerik, L. \& Håkansson, E. 1989: Stratigraphy and depositional history of the Upper Palaeozoic and Triassic sediments in the Wandel Sea Basin, eastern North Greenland. Rapp. Grønlands geol. Unders. 143.

Stoneley, R. 1981: Petroleum: the sedimentary basin. In Tarling, D. H. (edit.) Economic geology and geotectonics, 51-71. London: John Wiley \& Sons Ltd.

Stouge, S., Thomsen, E. \& Guvad, C. 1988: Reflected light microscopy of graptolite periderm material of Ordovician/ Silurian strata in North Greenland. Unpubl. intern. GGU rep., 58 pp.

Strother, P. K. \& Traverse, A. 1979: Plant microfossils from Llandoverian and Wenlockian rocks of Pennsylvania. Palynology 3, 1-21.

Stuart-Smith, J. H. 1970: Hydrocarbon potential of northern Greenland. Bull. Am. Ass. Petrol. Geol. 54, 2507 only.

Stuart-Smith, J. H. \& Wennekers, J. H. N. 1977: Geology and hydrocarbon discoveries of Canadian Arctic Islands. Bull. Am. Ass. Petrol. Geol. 61, 1-27.

Surlyk, F. 1982: Nares Strait and the down-current termination of the Silurian turbidite basin of North Greenland. In Dawes, P. R. \& Kerr, J. W. (edit.) Nares Strait and the drift of Greenland: a conflict in plate tectonics. Meddr Grønland Geosci. 8, 147-150.

Surlyk, F. 1983: Source rock sampling, stratigraphical and sedimentological studies in the Upper Palaeozoic of the Jameson Land basin, East Greenland. Rapp. Grønlands geol. Unders. 115, 88-93.

Surlyk, F. \& Hurst, J. M. 1983: Evolution of the early Paleozoic deep-water basin of North Greenland - aulacogen or narrow ocean? Geology 11, 77-81.

Surlyk, F. \& Hurst, J. M. 1984: The evolution of the early Paleozoic deep-water basin of North Greenland. Bull. geol. Soc. Am. 95, 131-154.

Surlyk, F., Hurst, J. M., Marcussen, C., Piasecki, S., Rolle, F., Scholle, P. A., Stemmerik, L. \& Thomsen, E. 1984: Oil geological studies in the Jameson Land basin, East Greenland. Rapp. Grønlands geol. Unders. 120, 85-90.

Surlyk, F. \& Ineson, J. R. 1987a: Aspects of Franklinian shelf, slope and trough evolution and stratigraphy of North Greenland. Rapp. Gronlands geol. Unders. 133, 41-58.

Surlyk, F. \& Ineson, J. R. 1987b: The Navarana Fjord Member (new) - an Upper Llandovery platform derived carbonate conglomerate. Rapp. Grønlands geol. Unders. 133, 59-63.

Thickpenny, A. \& Leggett, J. K. 1987: Stratigraphic distribution and palaeo-oceanographic significance of European early Palaeozoic organic-rich sediments. In Brooks, J. \& 
Fleet, A. J. (edit.) Marine petroleum source rocks. Spec. Publ. geol. Soc. Lond. 26, 231-247.

Thomsen, E. \& Guvad, C. 1987: Organic petrology and thermal maturity of Lower Palaeozoic deposits from western and central North Greenland. Unpubl. intern. GGU rep., part 1 (text) $40 \mathrm{pp}$. and part 2 (figures) $49 \mathrm{pp}$

Tissot, B. P. \& Welte D. H. 1984: Petroleum formation and occurrence, 699 pp. Berlin, Heidelberg, New York, Tokyo: Springer Verlag.

Trettin, H. P. 1987: Pearya: a composite terrane with Caledonian affinities in northern Ellesmere Island. Can. J. Earth Sci. 24, 224-245.

Trettin, H. P. \& Balkwill, H. R. 1979: Contributions to the tectonic history of the Innuitian Province, Arctic Canada. Can. J. Earth Sci. 16, 748-769.

Trettin, H. P., Frisch, T. O., Sobczak, L. W., Weber, J. R., Law, L. R., Delaurier, I., Niblett, E. R. \& Whitnam, K. 1972: The Innuitian Province. In Price, R. A. \& Douglas, R. J. W. (edit.) Variation in tectonic styles in Canada. Spec. Pap. geol. Ass. Can. 11, 83-179.

Troelsen, J. C. 1949: Contributions to the geology of the area round Jørgen Brønlunds Fjord, Peary Land, North Greenland. Meddr Grønland 149(2), 29 pp.

Troelsen, J. C. 1950: Contributions to the geology of Northwest Greenland, Ellesmere Island and Axel Heiberg Island. Meddr Grønland 149(7), 85 pp.

Tyson, R. V. 1987: The genesis and palynofacies characteristics of marine petroleum source rocks. In Brooks, J. \& Fleet, A. J. (edit.) Marine petroleum source rocks. Spec. Publ. geol. Soc. Lond. 26, 47-67.
Ungerer, P., Bessis, F., Chenet, P. Y., Durand, B., Nogaret, A., Chiarelli, A., Oudin, J. L. \& Perrin, J. F. 1984: Geological and geochemical models in oil exploration; principles and practical examples. In Demaison, G. \& Murris, R. J. (edit.) Petroleum geochemistry and basin evaluation. Mem. Am. Ass. Petrol. Geol. 35, 53-77.

Vavrdová, N. 1984: Some plant microfossils of possible terrestrial origin from the Ordovician of Central Bohemia. Věstnik Ústředniho ústavu geologického 59, 165-170.

Venkatachala, B. S. 1981: Differentiation of amorphous organic matter types in sediments. In Brooks, J. (edit.) Organic maturation studies and fossil fuel exploration, 177-200. London: Academic Press.

Waples, D. W. 1985: Geochemistry in petroleum exploration, 232 pp. Dordrecht: Reidel Publ. Com.

Wedeking, K. W. \& Hayes, J. M. 1983: Carbonization of Precambrian kerogens. In Bjorøy et al. (edit.) Advances in organic geochemistry 1981, 546-553. London: Wiley \& Sons Ltd.

Welte, D. H., Kalkreuth, W. \& Hoefs, J. 1975: Age-trend in carbon isotopic composition in Palaeozoic sediments. Naturwissenschaften 62, 482-483.

Welte, D. H. \& Yukler, M. A. 1981: Petroleum origin and accumulation in basin evolution - a quantitative model. Bull. Am. Ass. Petrol. Geol. 65, 1387-1396.

Yarbrough, S. C. 1986: Oil and gas developments in Europe 1985. Bull. Am. Ass. Petrol. Geol. 70, 1578-1610. 
Plate 1. Kerogen

A. Sample with a relatively low $(0.21 \%$ TOC) kerogen content and a dominance of finely disseminated amorphous kerogen in a silica gel, Lafayette Bugt Formation, Nyeboe Land, GGU 316490-1, unsieved organic material.

B. As A., Lafayette Bugt Formation, Nyeboe Land, GGU $316490-2$, sieved organic material (on $10 \mu \mathrm{m}$ nylon mesh).

C. Sample with a relatively moderate $(1.15 \%$ TOC) kerogen content and small to moderate amounts of large amorphous kerogen particles, Thors Fjord Member, Nares Land, GGU 318007-18-1 unsieved organic material.

\section{Plate 2. Cambrian palynomorphs}

A. Acritarch-like folded alga. Middle Cambrian Sydpasset Formation, Freuchen Land, MGUH 19334 from GGU 315873-2; 139.5-13.9.

B. Acritarch-like folded alga. Middle Cambrian Sydpasset Formation, Freuchen Land, MGUH 19335 from GGU 315873-2; 150.6-7.0.

C. Two acritarch-like folded algae. Middle Cambrian Sydpasset Formation, Freuchen Land, MGUH 19336 (large light body), MGUH 19337 (dark small body), both from GGU 315873-2; 122.0-15.3.

D. Acritarch-like folded alga. Middle Cambrian, Ekspedition Bræ Formation, Freuchen Land, MGUH 19338 from GGU 324217-2; 139.2-14.9.

E. Acritarch-like folded alga. Middle Cambrian, Ekspedition Bræ Formation, Freuchen Land, MGUH 19339 from GGU $324300-2 ; 131.2-13.4$.

\section{Plate 3. Ordovician palynomorphs}

A. Acritarch. Upper Ordovician Troedsson Cliff Member, Washington Land, MGUH 19344 from GGU 316968-2; 145.3-17.8.

B. Acritarch. Upper Ordovician - Lower Silurian Aleqatsiaq Fjord Formation, Washington Land, MGUH 19345 from GGU $316085-4 ; 124.1-21.3$.

C. Graptolite fragment, Upper Ordovician Troedsson Cliff Member, Washington Land, MGUH 19346 from GGU 316968-2; 128.1-2.9.

D. Scolecodont, Upper Ordovician, Troedsson Cliff Member, Washington Land, MGUH 19347 from GGU 316968-2; 148.8-15.1.

E. Alga. Upper Ordovician - Lower Silurian Aleqatsiaq Formation, Nyeboe Land, MGUH 19348 from GGU 316103-2; 135.0-15.0.

F. Filamentous alga. Upper Ordovician - Lower Silurian Aleqatsiaq Formation, Washington Land, MGUH 19349 from GGU $316058-2 ; 135.1-4.2$.

\section{Plate 4. Silurian palynomorphs}

A. Chitinozoan, Angochitina cf. A. elongata. Upper Silurian Wulff Land Formation, Wulff Land, MGUH 19350 from GGU 315950-3; 136.9-17.2.

B. Chitinozoans, Linochitina erratica. Upper Silurian Wulff Land Formation, Wulff Land, MGUH 19351 from GGU 315950-2; 154.3-9.6.

C. Retiolites, graptolite fragment. Upper Silurian, Wulff Land Formation, Wulff Land, MGUH 19352 from GGU 315950-3; 155.1-11.1.

D. Graptolite fragment, Upper Silurian, Wulff Land Formation, Wulff Land, MGUH 19353 from GGU 315950-2; 127.3-5.7.

E.-H. Trilete spore-like bodies, figs $\mathrm{E}$ and $\mathrm{F}$ with a degraded bitumen-like appearance.

E. Lower Silurian Lafayette Bugt Formation, Washington Land, MGUH 19354 from GGU 211760-2; 143.3-17.2. F. Upper Silurian Wulff Land Formation, Wulff Land, MGUH 19355 from GGU 315950-3; 15950-3; 155.5-8.2.
D. As C., Thors Fjord Member, Nares Land, GGU $318007-$ $18-2$, sieved organic material (on $10 \mu \mathrm{m}$ nylon mesh).

E. Sample with a relatively large $(5.09 \%$ TOC) kerogen content and a dominance of large amorphous kerogen particles, Thors Fjord Member, Nares Land, GGU 318007-32-1, unsieved organic material.

F. As E., Thors Fjord Member, Nares Land, GGU $318007-$ $32-2$, sieved organic material (on $10 \mu \mathrm{m}$ nylon mesh).

Scale bar: $20 \mu \mathrm{m}$

F. Acritarch-like folded alga. Middle Cambrian, Ekspedition Bræ Formation, Freuchen Land, MGUH 19340 from GGU 324217-2; 141.9-11.4.

G. Lump of algal or spore-like elements. Middle Cambrian, Ekspedition Bræ Formation, Freuchen Land, MGUH 19341 from GGU 324300-2; 127.8-14.4.

H. Diad-like lump of algal or spore-like elements. Middle Cambrian, Ekspedition Bræ Formation, Freuchen Land, MGUH 19342 from GGU 314300-2; 138.5-17.8.

I. Lump of alga or spore-like elements. Middle Cambrian, Ekspedition Bræ Formation, Freuchen Land, MGUH 19343 from GGU 324300-2; 157.7-14.7.

Scale bar: $20 \mu \mathrm{m}$

G.-L. Spores with trilete rays. Upper Ordovician, Troedsson Cliff Member, Washington Land (Nøhr-Hansen \& Koppelhus, 1988).

G.-I. Besselia nunaatica, MGUH 17539 from GGU 316968-2; 125.5-8.3.

G. Distal view illustrating the minute ornamentation.

H. Equatorial view.

I. Internal proximal view.

J. Besselia nunaatica, two connected spores, internal proximal view, MGUH 17541 from GGU 316968-2; 155.1-11.9. K.-L. Besselia nunaatica. MGUH 17542 from GGU 316968-2; 123.8-15.9.

$\mathrm{K}$. Distal view illustrating the ornamentation.

L. Internal proximal view.

Scale bar: $20 \mu \mathrm{m}$

G. Upper Silurian Nyeboe Land Formation, Nyeboe Land, MGUH 19356 from GGU 319234-2; 119.3-11.0.

H. Upper Silurian Nyeboe Land Formation, Wulff Land, MGUH 19357 from GGU 319210-3; 130.6-21.4.

I. Spherical folded algae, acritarchs? Lower Silurian Lafayette Bugt Formation, Hall Land, MGUH 19358 from GGU 324157-2; 144.2-8.5.

J. Tubular structure. Upper Silurian Nyeboe Land Formation, Wulff Land, MGUH 19359 from GGU 319210-3; 146.6-16.5.

K. Tubular structure. Upper Silurian Nyeboe Land Formation, Nyeboe Land, MGUH 19360 from GGU 319234-2; 138.8-8.0.

L. Rounded drop-shaped palynomorphs. Lower Silurian Lafayette Bugt Formation, Washington Land, MGUH 19361 from GGU 316061-2; 137.1-14.8.

Scale bar: $20 \mu \mathrm{m}$. 
Plate 1. Kerogen

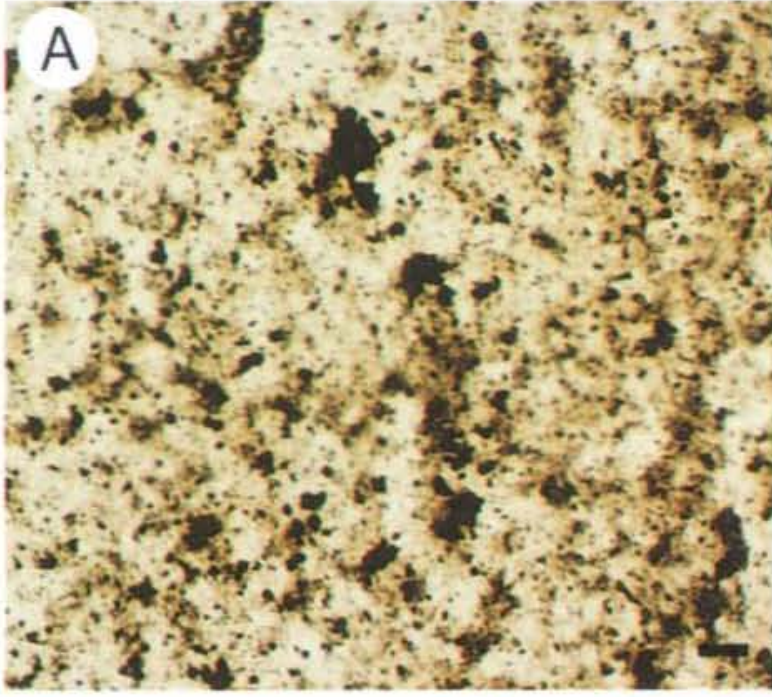

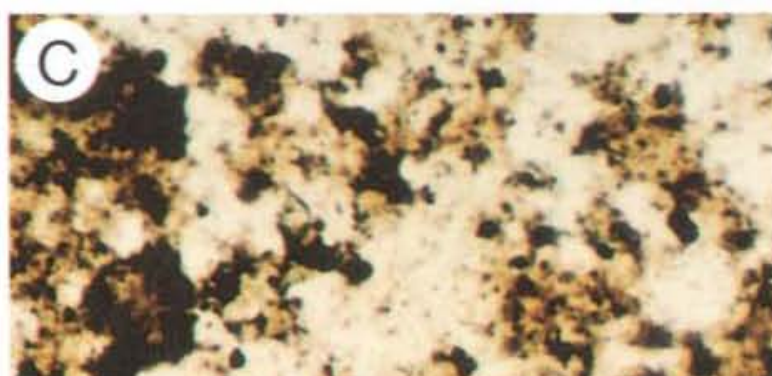

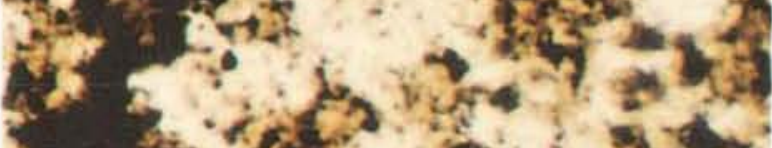

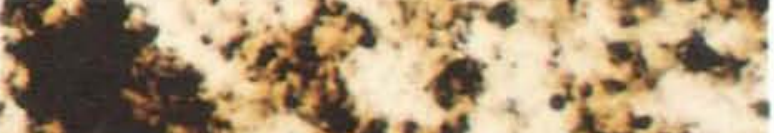

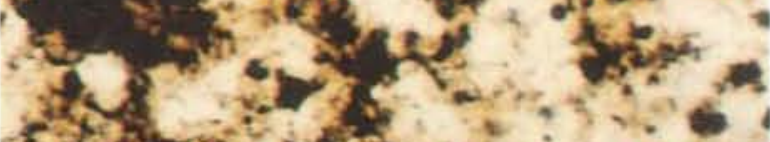
क्री

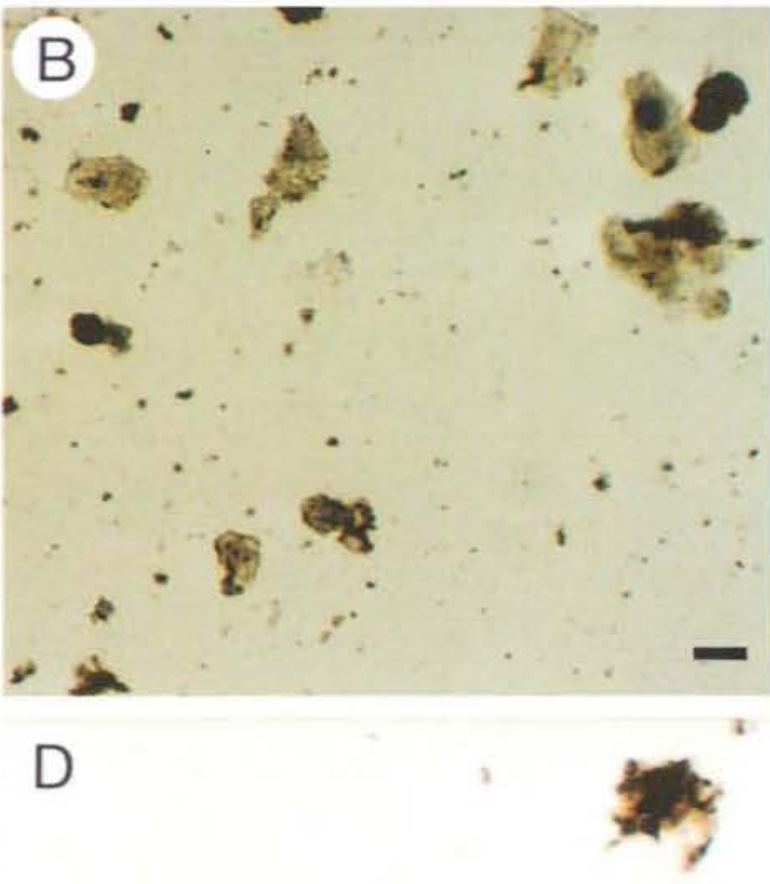

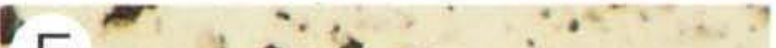
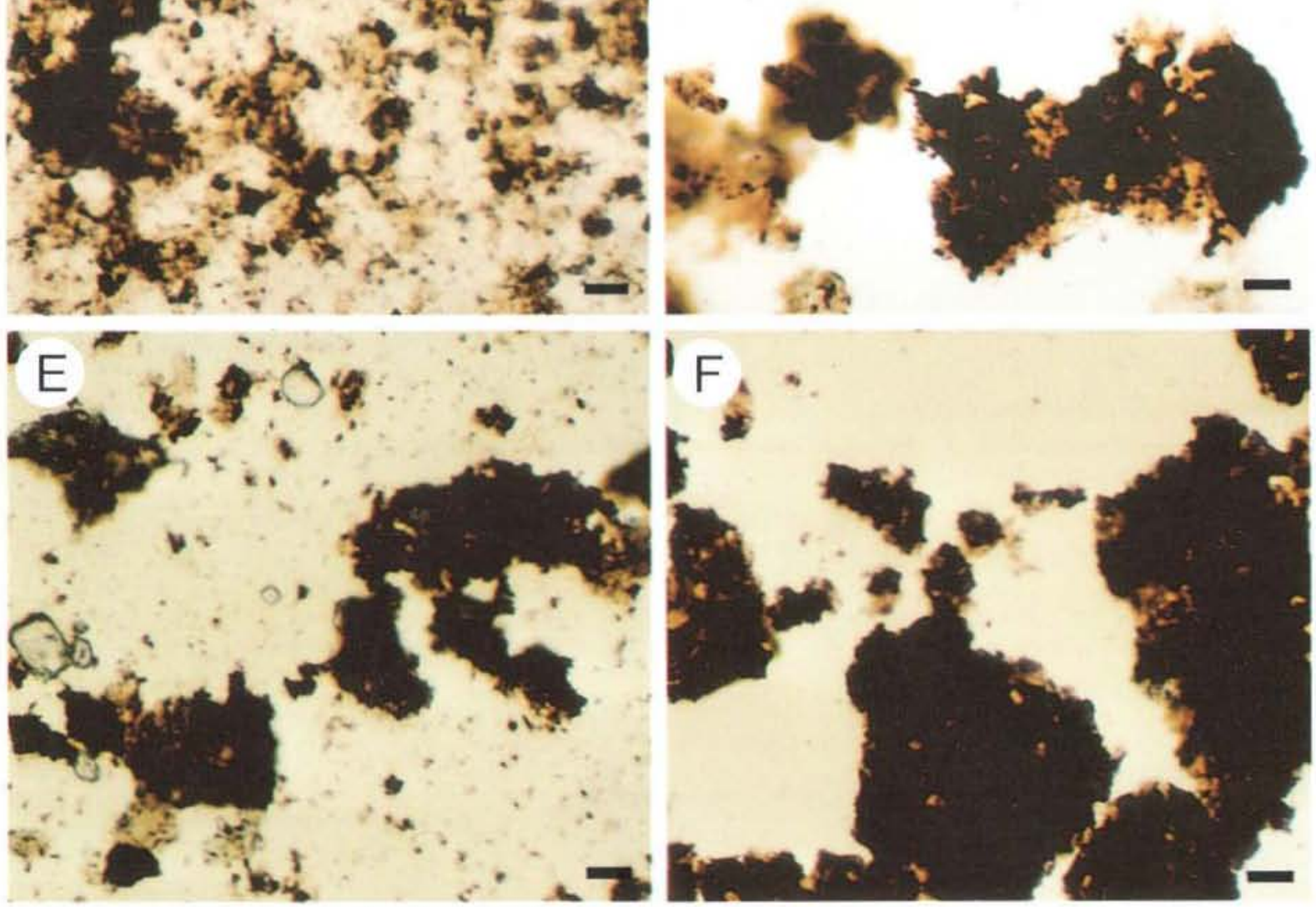
Plate 2. Cambrian palynomorphs

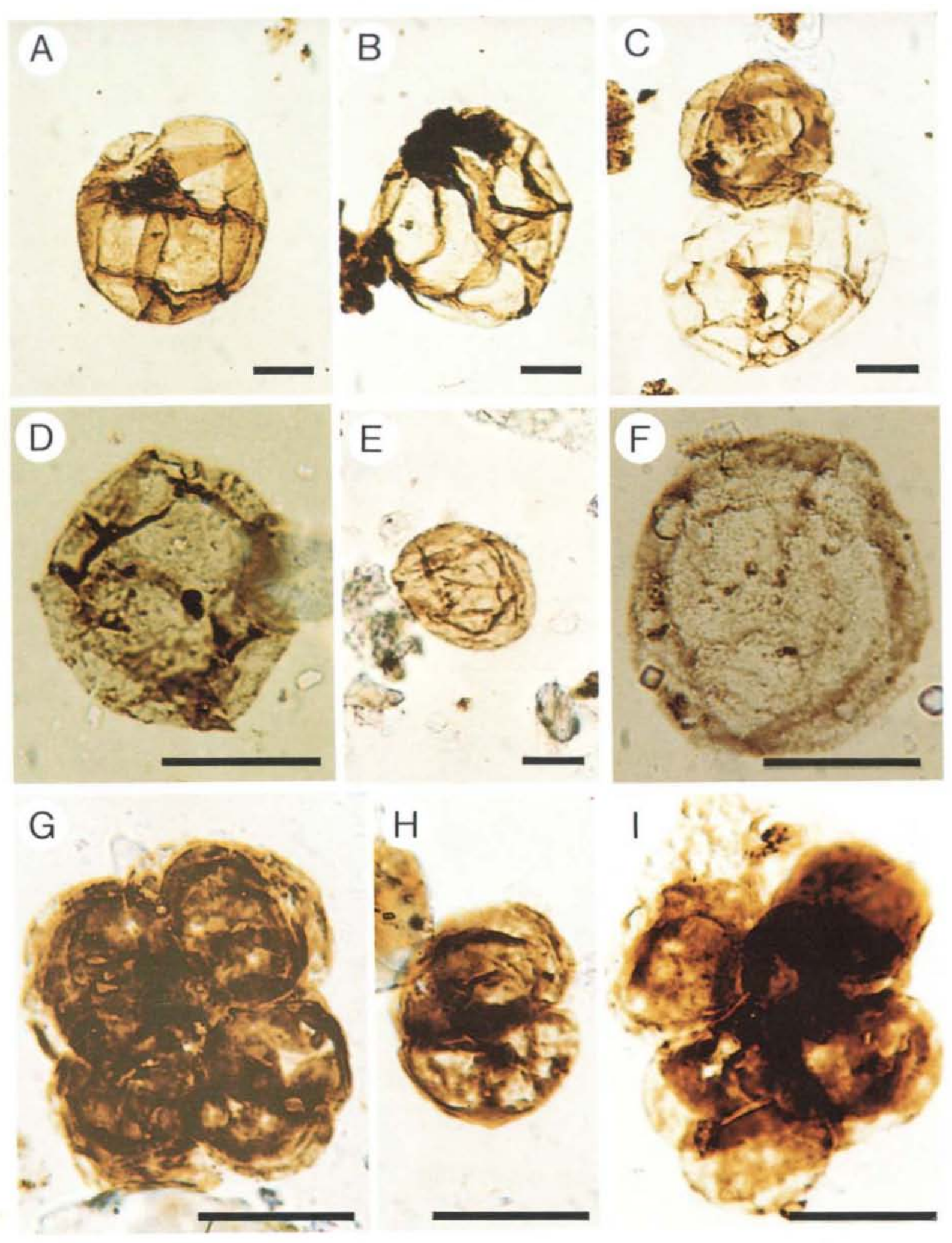


Plate 3. Ordovician palynomorphs
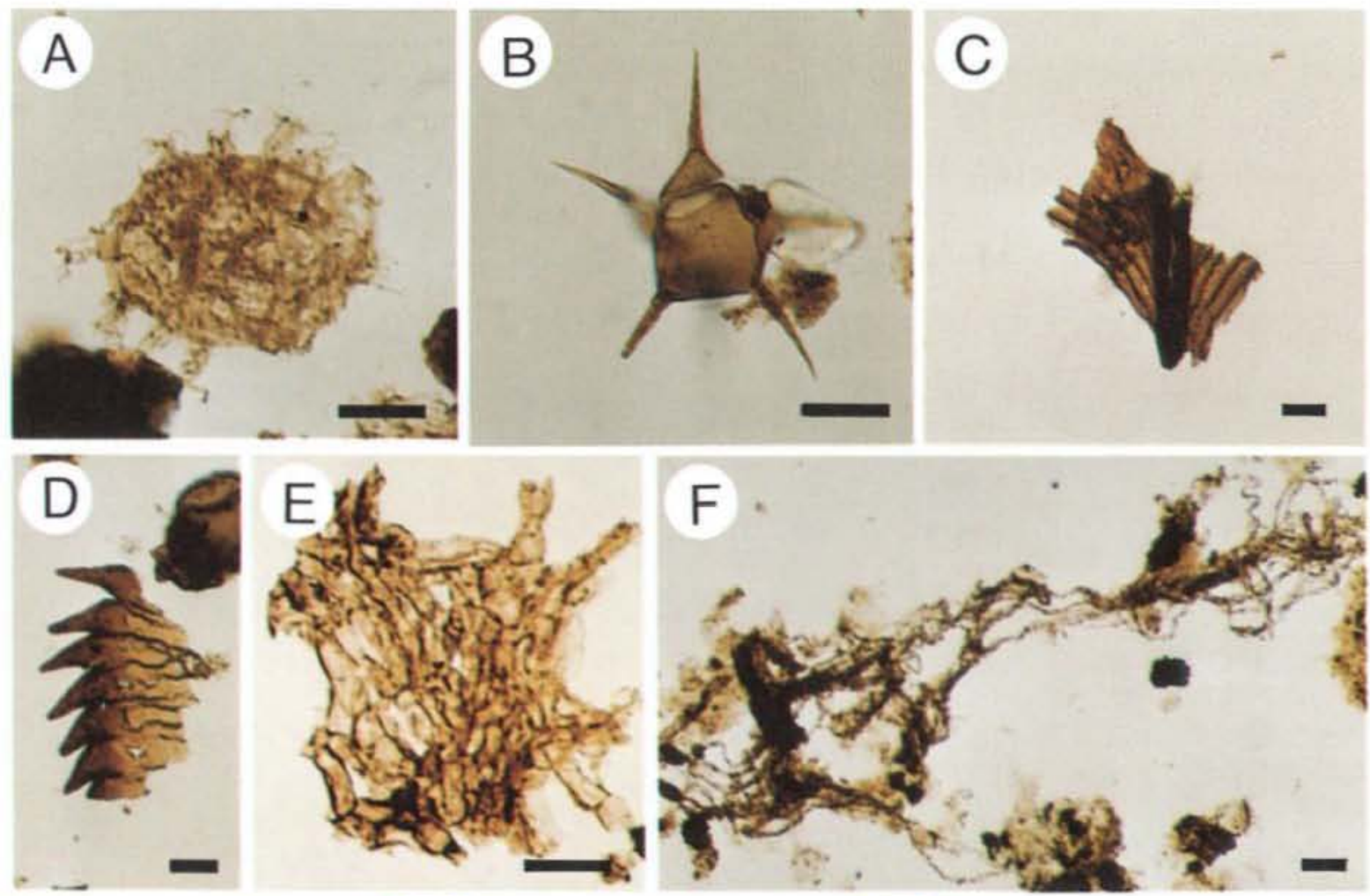

G
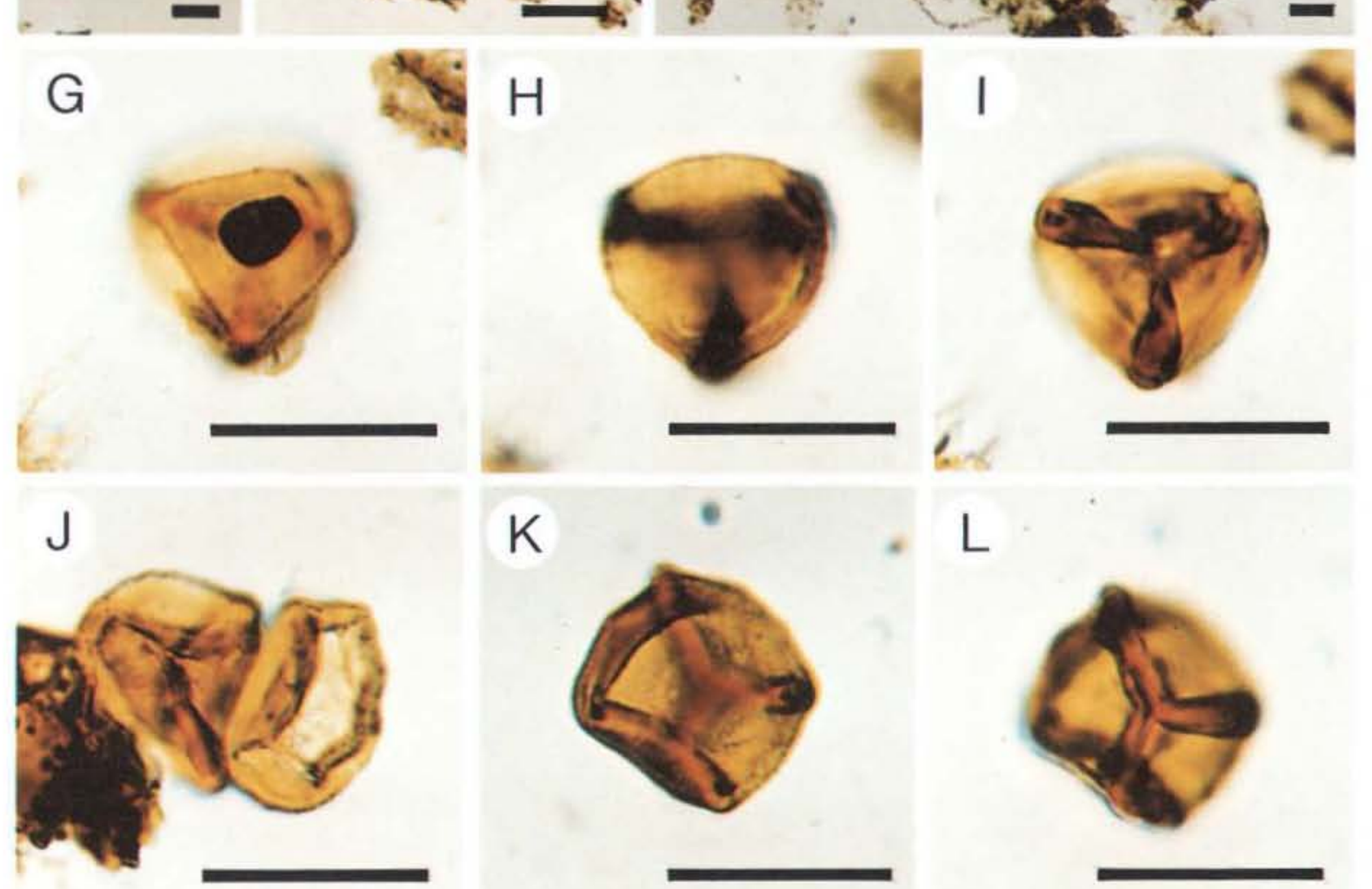
Plate 4. Silurian palynomorphs

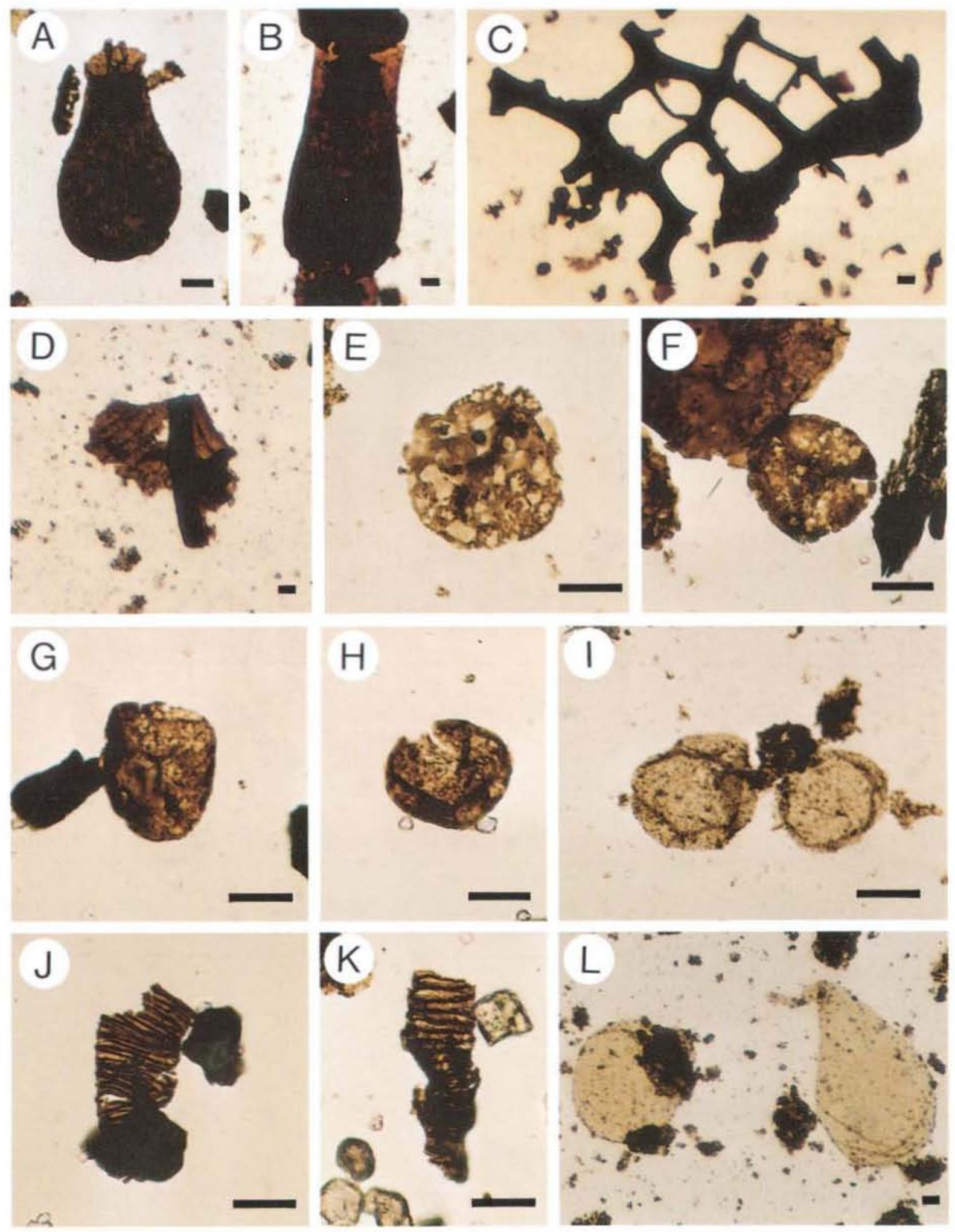


Plate 5. Progressive coloration of amorphous kerogen with increasing thermal alteration
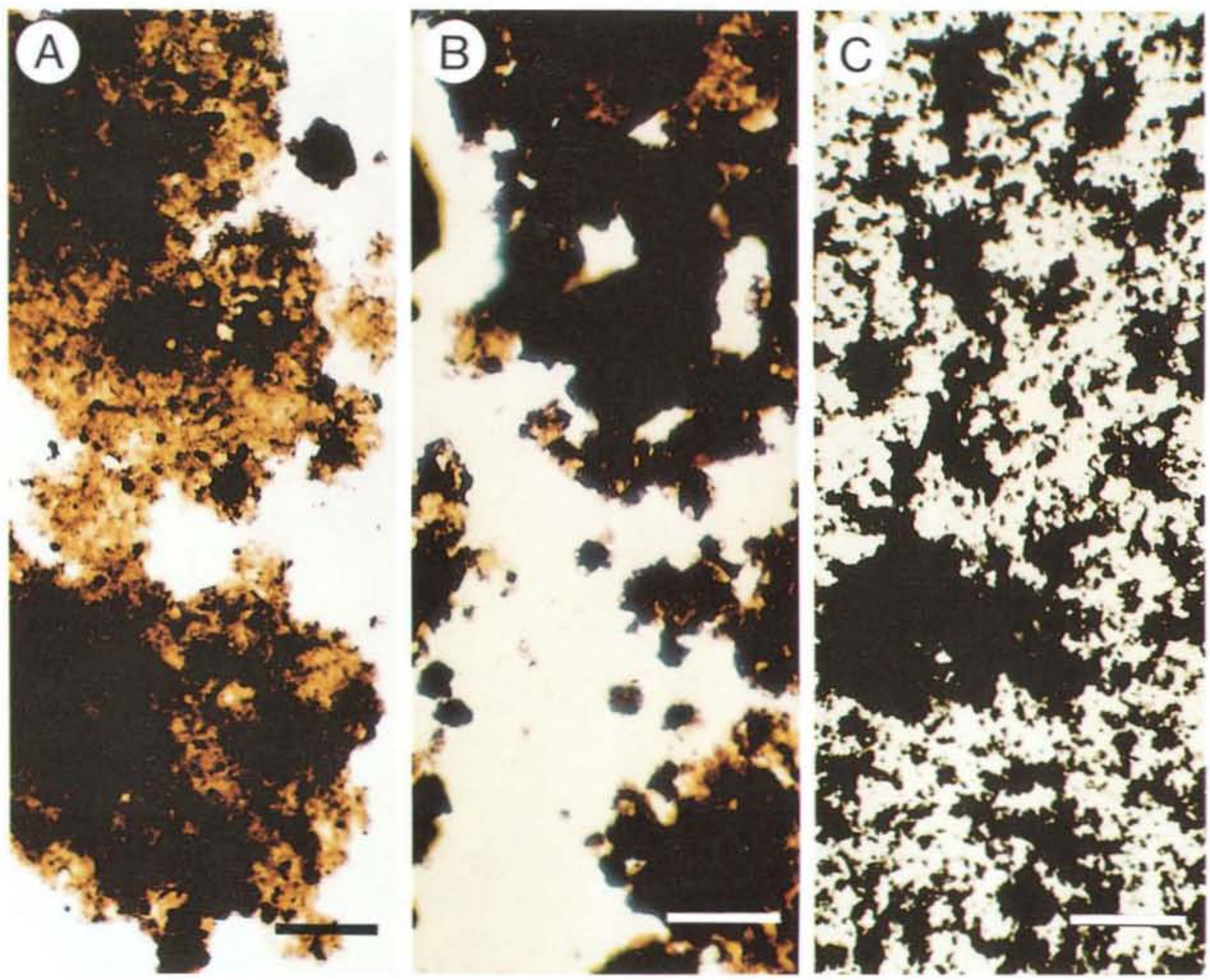

Plate 5. Progressive coloration of amorphous kerogen with increasing thermal alteration Scale bar: $50 \mu \mathrm{m}$
A. TAI: (2)-2+, GGU $211759-2$.
B. TAI: $2^{+}-\left(3^{-}\right)$, GGU $324405-2$.
C. TAI: $4^{+}$, GGU $316475-1$. 
Plate 6. Change in structure of amorphous kerogen with increasing thermal alteration as observed in the scanning electron microscope
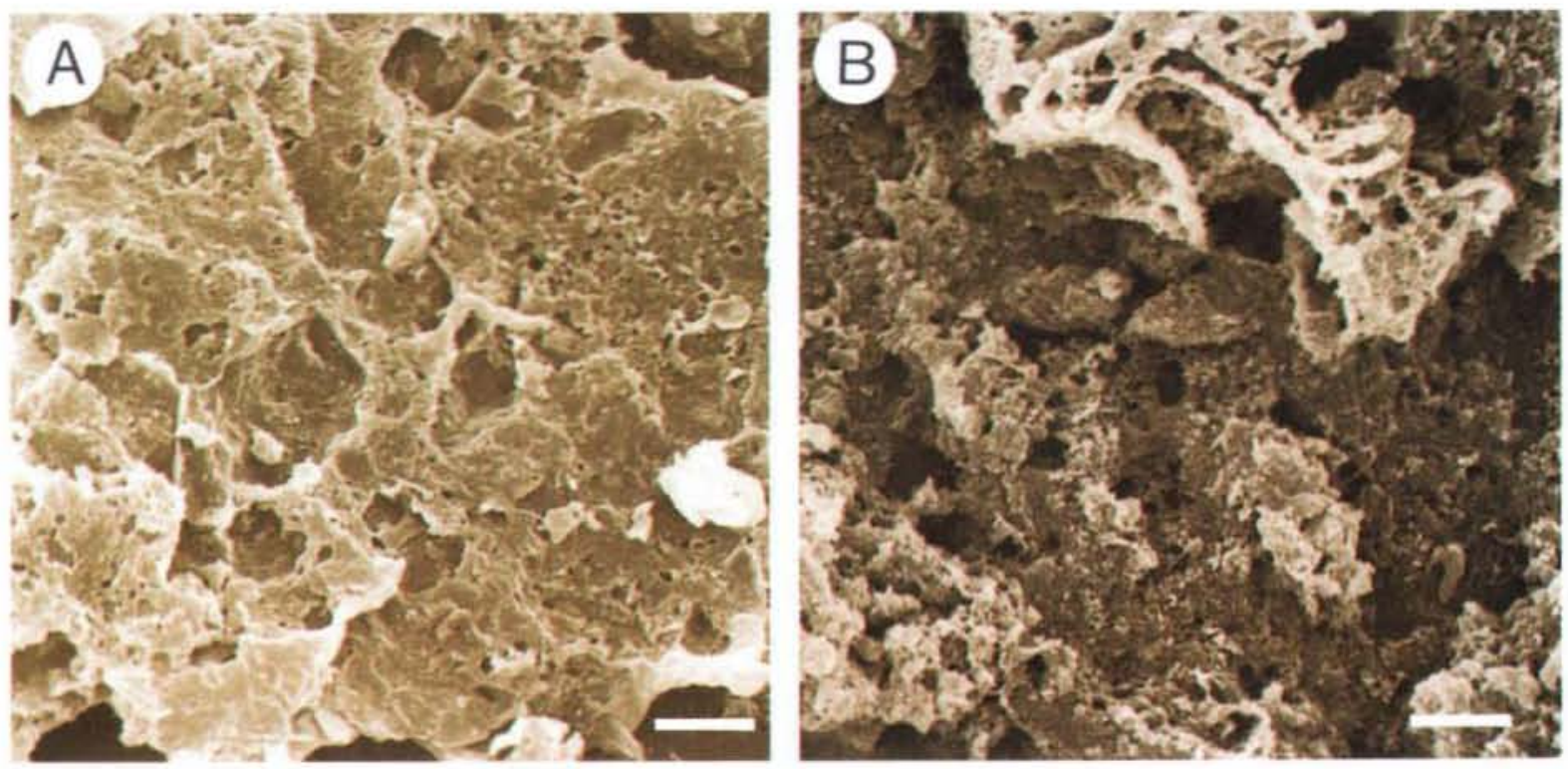

Plate 6. Change in structure of amorphous kerogen with increasing thermal alteration as observed in the scanning electron microscope

A. TAI: $2^{*}-(3), T_{\max }: 446$, GGU $324405-2$, scale bar: $10 \mu \mathrm{m}$.

Plate 7. Field appearance of bitumen

A. Seeping asphalt from southern Wulff Land (equivalent to GGU 324200).

Plate 8. Macroscopic bitumen in slabs

A. Asphalt from seep in dolomite breccia. GGU $324200 \mathrm{~A}$.

B. Like A. Stained. D0, D1, D2, C1, C2 correspond to generations of dolomite and calcite.

\section{Plate 9. Bitumen in thin section}

A. Bitumen in coral. GGU 324130B, Lafayette Bugt Formation. Nyeboe Land. Plane light, stained, C: calcite, Fe-C: Fe-rich calcite, B: bitumen, scale bar: $1 \mathrm{~mm}$.

B. Bitumen in coral. GGU 316067, Lafayette Bugt Formation, Washington Land. Crossed nicols + gypsum plate. Q: quartz, C: calcite, B: bitumen, scale bar: $1 \mathrm{~mm}$.

C. Bitumen-filled fracture in calcarenite. GGU 318013-09, Lafayette Bugt Formation. Nyeboe Land. Plane light, scale bar: $2 \mathrm{~mm}$.
B. TAI: $4^{*}, T_{\max }: \mathrm{n} . \mathrm{d}$, GGU $316475-2$, scale bar: $10 \mu \mathrm{m}$.

B. Hard solid bitumen in dolomite vug in the Sydpasset Formation (equivalent to GGU 324287-324299, core GGU 318003).

C. Asphalt from seep in dolomite breccia. Stained. Same generations of carbonates as A and B. GGU $324200 \mathrm{E}$.

D. Hard solid bitumen in vugs and veins in dolomite grainstone. DO: dolomite grainstone, D1: saddle dolomite. Core GGU 318003 .

D. Two-phased bitumen (black and yellow) (B1, B2) in saddle dolomite veins (D1) cross-cutting dolomite grainstone (D0). See close-up (arrow) in Plate 11. GGU 318003-53, Henson Gletscher Formation, Freuchen Land. Plane light, scale bar: $2 \mathrm{~mm}$.

E.-F. Saddle dolomite vein (D1) in dolomite grainstone (D0). Bitumen occurs as impregnation in DO (B1), as residual matter in the contact between D0 and D1 (B2, $R_{0}: 0.92 \%$ ) and in the centre of the vein (B3, $R_{v}: 1.21 \%$ ). GGU 318003-21. Sydpasset Formation, Freuchen Land. Plane light, scale bars: $1 \mathrm{~mm}$.

Plate 10. Bitumen in palynologically prepared samples observed in microscope or in SEM

A. Bitumen with flaky appearance (note crystal impressions). GGU 315172-1. Ryder Gletscher Group Fm 6, Wulff Land. Scale bar: $25 \mathrm{um}$.

B. Globular bitumen. GGU 315865-2, Aftenstjernesø Formation, Nares Land, scale bar: $50 \mu \mathrm{m}$.

C. Globular bitumen which has been extruded during and after sample preparation by the xylene-containing mounting medium. GGU 315199, Ryder Gletscher Group Fm 6. Warming Land. Scale bar: $12.5 \mu \mathrm{m}$.
D. Bitumen with flaky appearance (note crystal impressions). GGU 315172-1. Ryder Gletscher Group Fm 6, Wulff Land. Scale bar: $10 \mu \mathrm{m}$.

E. Bitumen mirroring imprints of crystals from coral space. GGU 316067-2. Lafayette Bugt Formation, Washington Land. Scale bar: $10 \mu \mathrm{m}$.

F. Thread-like bitumen. GGU 324453, Buen Formation, Wulff Land. Scale bar: $25 \mu \mathrm{m}$. 
Plate 7. Field appearance of bitumen

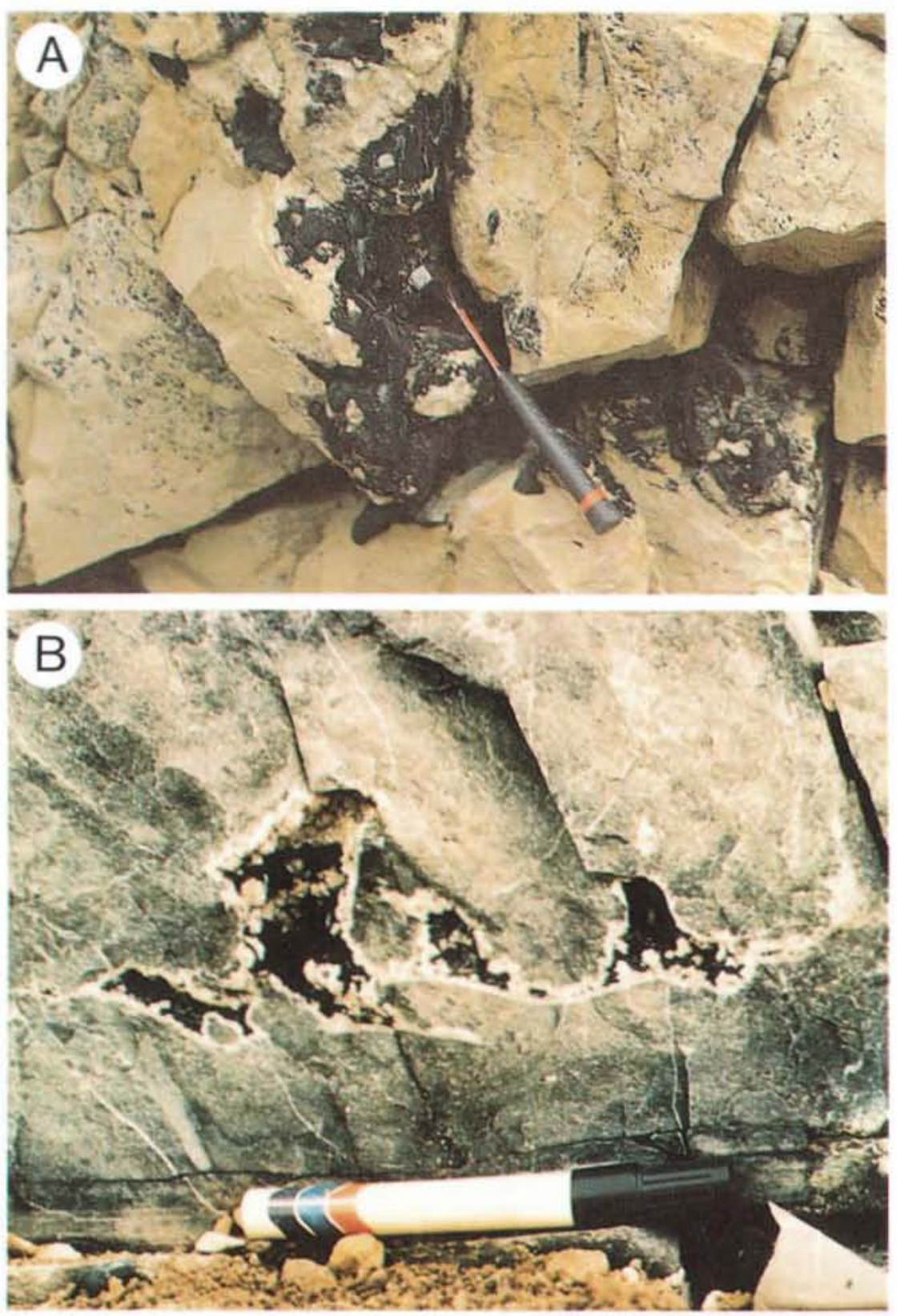


Plate 8. Macroscopic bitumen in slabs
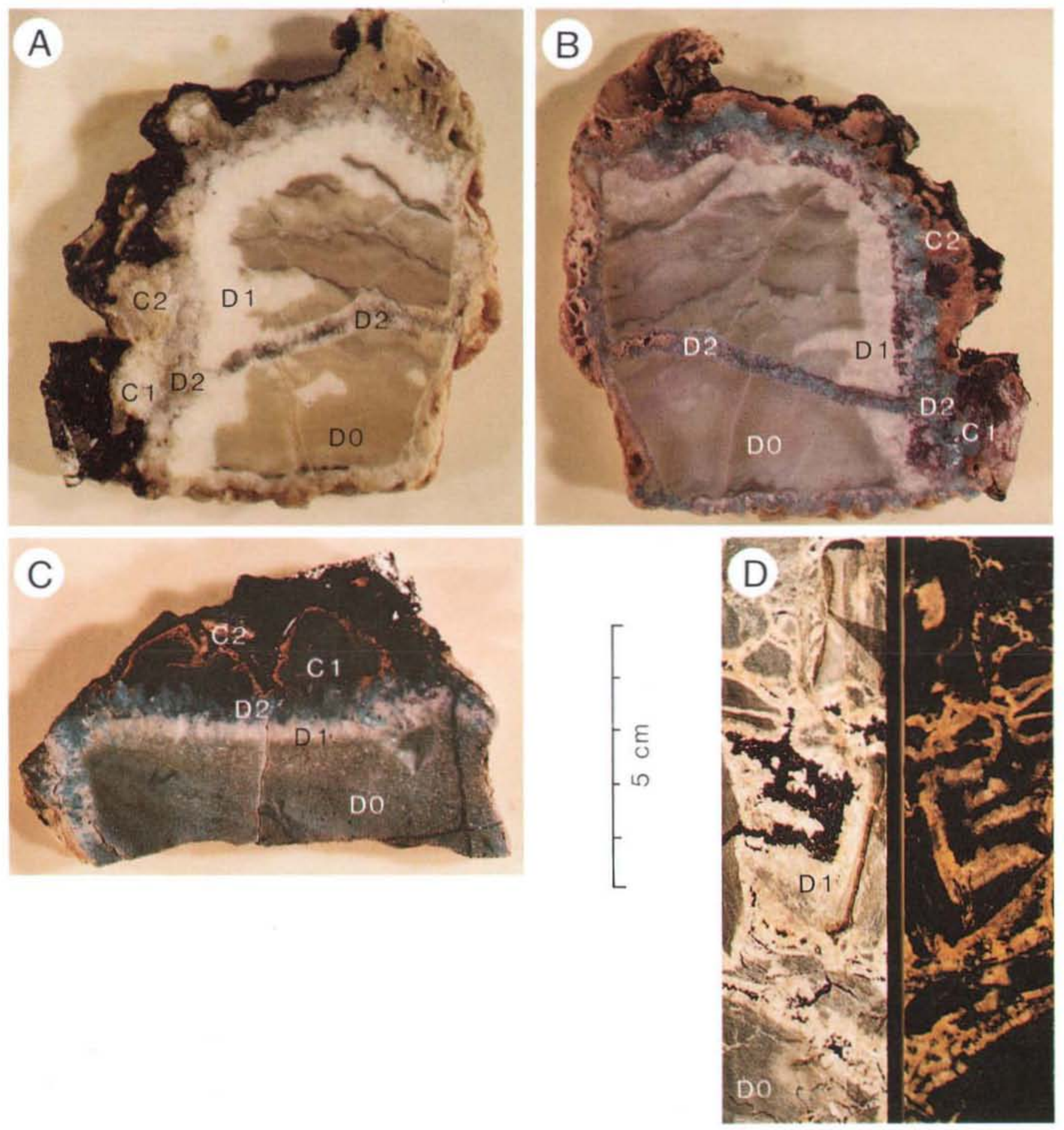
Plate 9. Bitumen in thin section

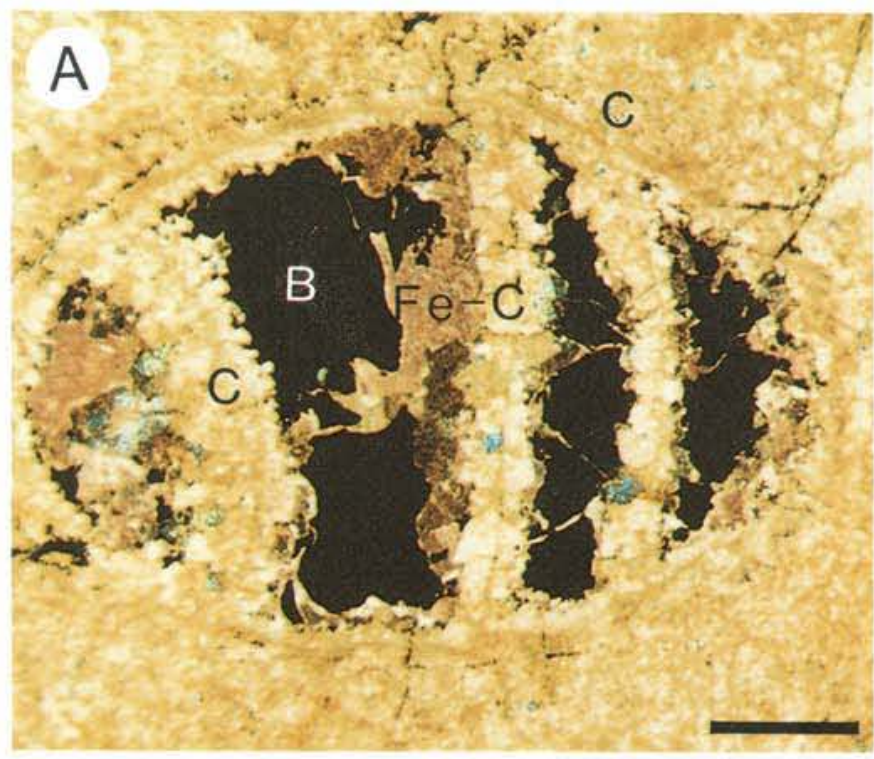

C

F. Af:
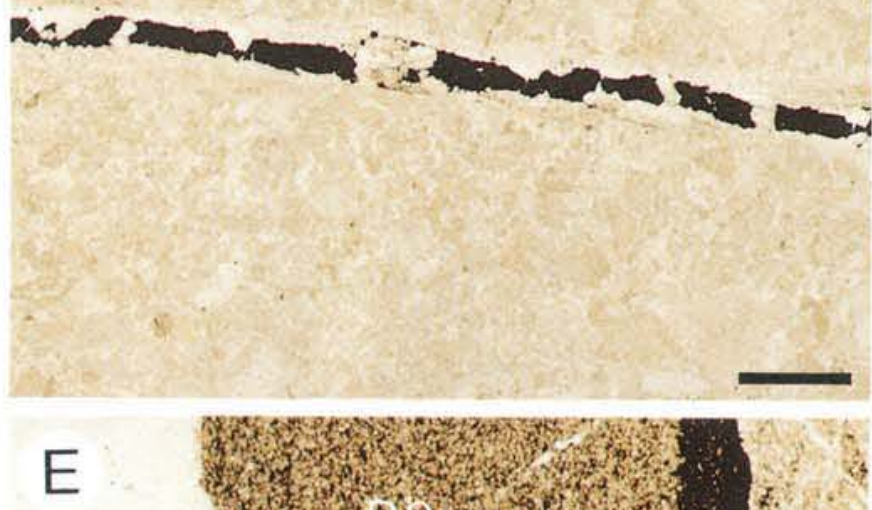

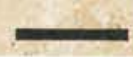

E

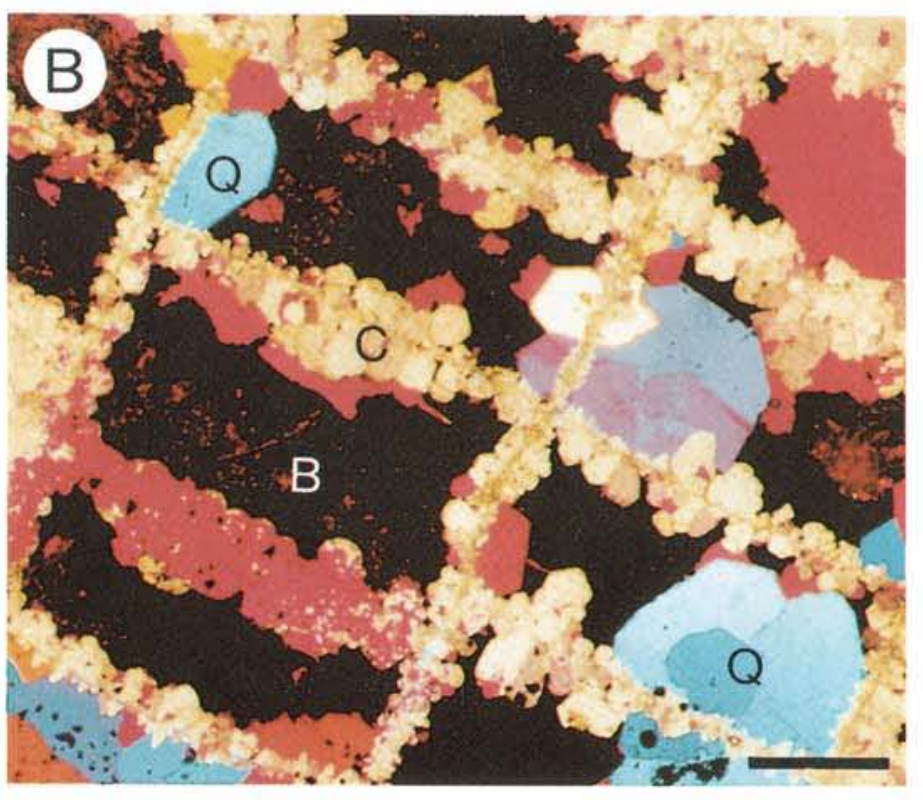

D

Dó

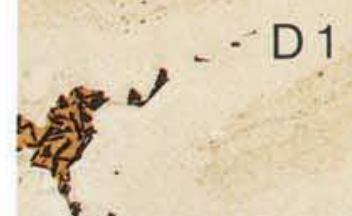

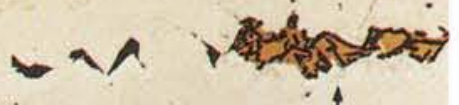 \\ $\mathrm{B} 1,{ }^{4} \mathrm{~B} 2$}

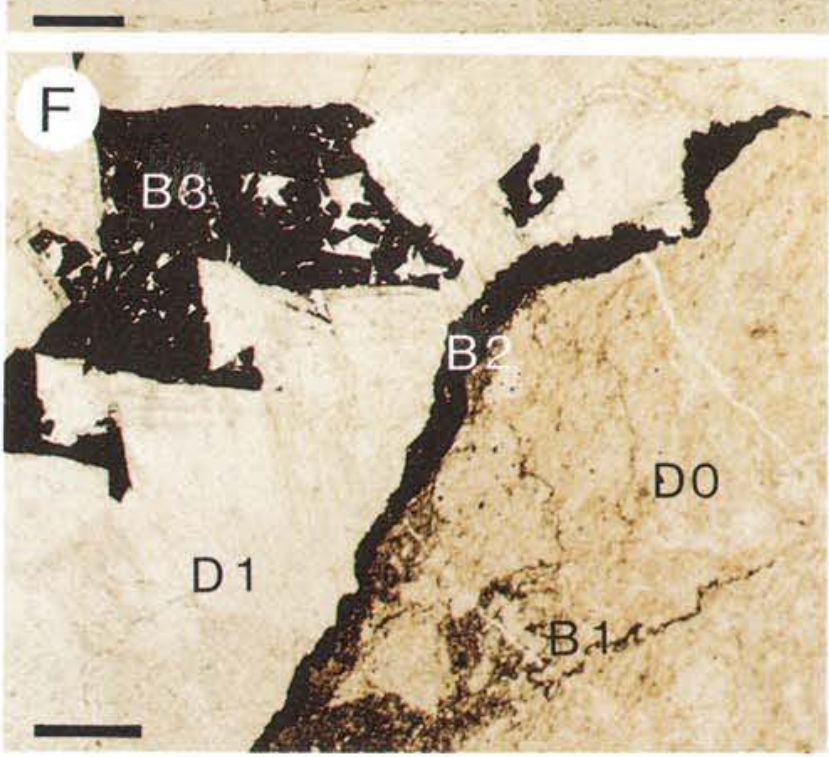


Plate 10. Bitumen in palynologically prepared samples observed in microscope or in SEM
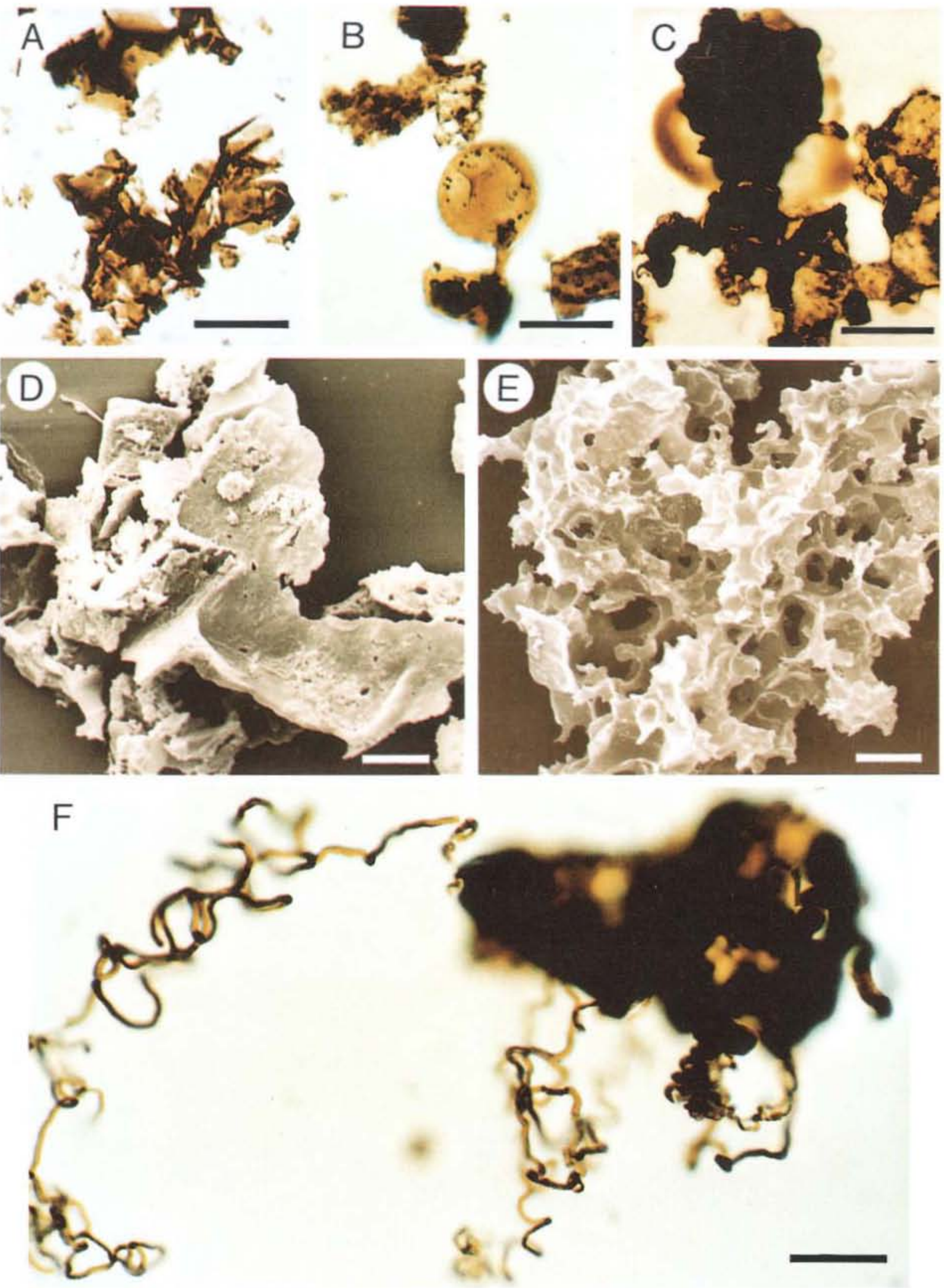
Plate 11. Bitumen in polished section
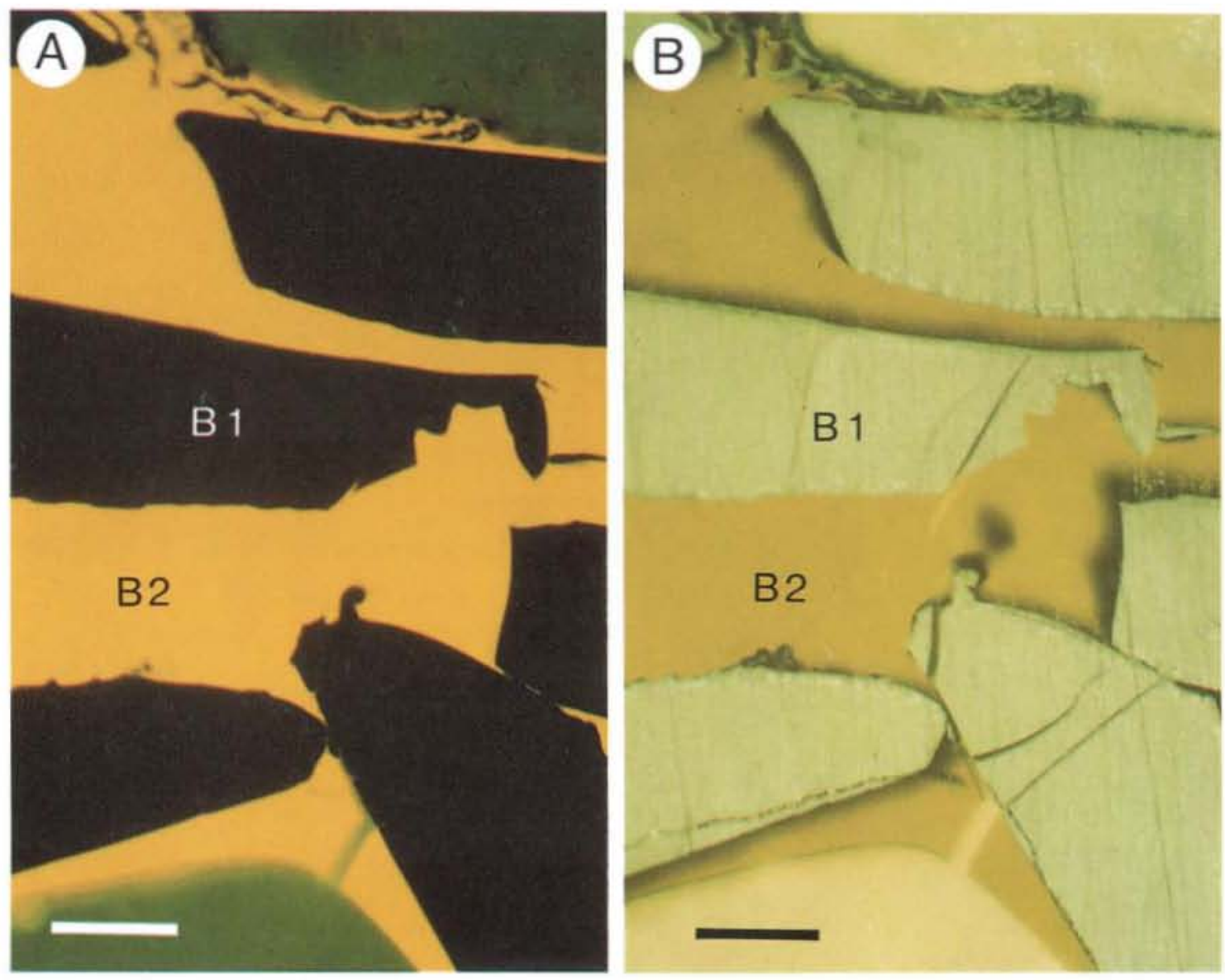

Plate 11. Bitumen in polished section

GGU 318003-53, Henson Gletscher Formation, Freuchen Land.

Scale bar: $50 \mu \mathrm{m}$

A. Fluorescent light photograph of two-phase bitumen.

B. Normal reflected light photograph of same field. The yellow-fluorescent low-reflecting bitumen (B2) has a $\mathbf{R}_{\mathrm{o}}$ of $0.08 \%$ and the dark non-fluorescent high-reflecting bitumen (B1) a $\mathrm{R}_{\mathrm{o}}$ of $1.17 \%$.

\section{Cover picture}

Cambrian and Ordovician strata at Blue Cliffs, Wulff Land, North Greenland. Photo: J. Lautrup, GGU. 